\title{
On the systematic position of the diving-beetle genus Pachydrus (Coleoptera: Dytiscidae: Hydroporinae): Evidence from larval chaetotaxy and morphology
}

\author{
Mariano C. MiCHAT ${ }^{1,2}$ and Patricia L.M. TORRES ${ }^{1}$
}

\begin{abstract}
${ }^{1}$ CONICET
${ }^{2}$ Laboratorio de Entomología, Departamento de Biodiversidad y Biología Experimental, Facultad de Ciencias Exactas y Naturales, Universidad de Buenos Aires, Av. Int. Güiraldes s/n, Ciudad Universitaria, C1428EHA, Buenos Aires, Argentina; e-mail: marianoide@gmail.com
\end{abstract}

Key words. Diving beetles, Dytiscidae, Hyphydrini, Pachydrus, larva, chaetotaxy, phylogeny

\begin{abstract}
Phylogenetic relationships within the diving-beetle subfamily Hydroporinae are not well understood. Some authors include the genus Pachydrus Sharp, 1882 in the tribe Hyphydrini, whereas others are in favour of excluding Pachydrus from the Hyphydrini and placing it in its own tribe, Pachydrini. Larval characters have been underutilised in phylogenetic studies, mainly because the larvae of many taxa within the family are unknown. In this study, the phylogenetic relationships of Pachydrus are studied based on a cladistic analysis of 34 taxa and 122 morphological larval characters. For this purpose, larvae of $P$. obesus Sharp, 1882 are described and illustrated in detail for the first time, with particular emphasis on morphometry and chaetotaxy. First and second instars for the genus were unknown. The results support a monophyletic origin of the tribe Hyphydrini excluding Pachydrus, based on four unique character states. On the other hand, Pachydrus is resolved as the sister group of the Hydrovatini. These results suggest Pachydrus should not be placed in the Hyphydrini. Given that the Hyphydrini minus Pachydrus is a distinctive clade, based on this study, it seems useful to recognise this group as Hyphydrini. Including Pachydrus in Hyphydrini would leave the tribe with a single larval apomorphy, as most characters present in the Hyphydrini and Pachydrus are also present in the Hydrovatini. However, in the absence of larvae of Heterhydrus Fairmaire, 1869 and of a more comprehensive and inclusive analysis, we do not propose a formal exclusion of Pachydrus from Hyphydrini at this stage. Pachydrus is a highly distinctive genus within the Hydroporinae and is characterised by several larval apomorphies.
\end{abstract}

\section{INTRODUCTION}

Pachydrus Sharp, 1882 is a diving-beetle genus including nine species, all inhabiting the New World (Biström et al., 1997; Nilsson, 2001). The genus includes small-sized individuals of globous shape, and is predominantly Neotropical, with one species $[P$. princeps (Blatchley, 1914)] reaching the Southeast of the Nearctic Region. Pachydrus obesus Sharp, 1882, the type species of Pachydrus, is widely distributed in South America, from Venezuela and Brasil to central Argentina (Trémouilles 1995).

Pachydrus is most commonly included in the tribe Hyphydrini of the subfamily Hydroporinae. Hyphydrini includes 15 genera (Nilsson, 2001) of which only two are present in America, Desmopachria Babington, 1841 and Pachydrus. The phylogenetic position of Pachydrus has been controversial for many years. The genus was initially included (along with Heterhydrus Fairmaire, 1869) in the tribe Bidessini since the adults have the metacoxae fused to the basal abdominal sternite (Sharp, 1882). Zimmermann (1919) transferred both genera to the tribe Hyphydrini, characterised by the metatarsal claws unequal in length (Biström, 1982; Miller, 2001). Young (1980) emphasised that, even though Pachydrus is commonly included in the tribe Hyphydrini, it is not closely related to the old-world Hyphydrini genera and suggested that the genus should be placed in a new tribe, Pachydrini. Biström et al. (1997), based on a cladistic analysis including all Hyphydrini genera, found that the clade Pachydrus + Heterhydrus was resolved as the sister group of the remaining Hyphydrini. Biström et al. (1997) postulated that Hyphydrini including Pachydrus was polyphyletic, formally transferred Pachydrus and Heterhydrus to Pachydrini and proposed several adult apomorphies for the tribe. However, Miller (2001) based on a broad cladistic analysis of adult characters, found that Hyphydrini (including Pachydrus and Heterhydrus) is monophyletic and is supported by two apomorphies: the obliteration of the metacoxal lobes and metatarsal claws of unequal length. Miller (2001) criticised Biström's et al. (1997) analysis, rejected the use of Pachydrini and transferred Pachydrus and Heterhydrus back to Hyphydrini, a synonymy recognised by Nilsson (2001) and supported by Miller et al. (2006). On the other hand, studies based on larval morphology (Alarie et al., 1997; Alarie \& Challet, 2006a, b) suggest a monophyletic origin of the tribe Hyphydrini including Pachydrus, and a position of Pachydrus (Heterhydrus not considered) as the sister group of the remaining Hyphydrini. However, Miller (2001) found that Pachydrus and Heterhydrus are more closely related to Desmopachria. All this reflects the differences in opinion regarding the systematic position of Pachydrus within the Hydroporinae and indicates a need for more studies, including of character sets not so far explored for the genus, such as primary larval chaetotaxy. 
The larval morphology of Pachydrus is scarcely known, only the third-instar larva is described. The larvae of four species are known: $P$. princeps (Spangler \& Folkerts, 1973), P obesus (Crespo, 1996), P. globosus (Aubé, 1838) (Alarie et al., 1997) and P. obniger (Chevrolat, 1863) (Alarie \& Megna, 2006). Also, a short description of the third-instar larva of an unidentified species of Pachydrus is presented by Bertrand (1968). Unfortunately, these descriptions include only the mature larva, so the primary chaetotaxy was not studied. Larval chaetotaxy is important in the study of the phylogenetic relationships within Dytiscidae, as reflected in several recent papers presenting phylogenetic hypotheses regarding the different groups within the family (e.g., Michat \& Torres, 2005; Alarie \& Challet, 2006a, b; Michat, 2006; Shaverdo \& Alarie, 2006 Alarie \& Michat, 2007b; Michat et al., 2007; Michat \& Alarie, 2008). The recent development of a system of nomenclature for the primary sensilla of first-instar larvae of some dytiscid subfamilies, such as the Hydroporinae (Alarie \& Harper, 1990; Alarie et al., 1990a; Alarie, 1991a; Alarie \& Michat, 2007a), allows the exploration of new sets of characters that are useful in a phylogenetic sense.

The poor knowledge of the larval morphology of Pachydrus and the lack of phylogenetic hypotheses about the relationships of this genus based on larval characters, make the discovery of the larvae of P. obesus of great interest. The current study had the following goals: (1) description and illustration, for the first time, of the first two larval instars of a species of Pachydrus (third instar is redescribed), including detailed morphometric and chaetotaxic analyses of selected structures; and (2) a cladistic study of the phylogenetic relationships of Pachydrus within the Hydroporinae based on larval characters.

\section{MATERIAL AND METHODS}

\section{Source of material}

Three specimens of instar I, two of instar II and five of instar III of $P$. obesus were used for the descriptions. Larvae were collected in association with adults at the following locality: Argentina, Corrientes Province, Mburucuyá National Park, 6.-15.xi.1997 and 15.i.2008, large permanent pond with irregular margins, clear water, muddy bottom with organic debris and abundant emergent and floating vegetation (Salvinia sp., Eichhornia sp.). The identification of the larvae is clear as $P$. obesus was the only Pachydrus species found as adults at that locality.

\section{Methods}

Specimens were cleared in lactic acid, dissected and mounted on glass slides in polyvinyl-lacto-glycerol. Observation (at magnifications up to $1000 \times$ ) and drawings were made using an Olympus CX31 compound microscope equipped with a camera lucida. Drawings were scanned and digitally edited. The material is held in the larval collection of M.C. Michat (Laboratory of Entomology, Buenos Aires University, Argentina).

\section{Morphometric analysis}

We employed, with minimal modifications and additions, the terms used in previous papers dealing with the larval morphology of Hydroporinae (Alarie \& Challet, 2006a, b; Alarie \& Michat, 2007b; Michat et al., 2007). Paired structures of each individual were considered independently. The following measurements were taken (with abbreviations shown in parentheses). Total length (excluding urogomphi) (TL); maximum width (MW); head length (HL) (total head length including the frontoclypeus, measured medially along the epicranial stem); maximum head width (HW); length of frontoclypeus (FRL) (from apex of nasale to posterior margin of ecdysial suture); occipital foramen width (OCW) (maximum width measured along dorsal margin of occipital foramen); coronal line length (COL); length of mandible (MNL) (measured from laterobasal angle to apex); width of mandible (MNW) (maximum width measured at base). Lengths of antenna (A), maxillary (MP) and labial (LP) palpi were obtained by adding the lengths of the individual segments; each segment is denoted by the corresponding letter(s) followed by a number (e.g., A1, first antennomere). A3' is used as an abbreviation for the apical lateroventral process of the third antennomere. Length of leg $(\mathrm{L})$, including the longest claw (CL), was obtained by adding the lengths of the individual segments; each leg is denoted by the letter L followed by a number (e.g., L1, prothoracic leg). The length of trochanter includes only the proximal portion, the length of distal portion is included in the femoral length. The legs of the larvae studied were considered as being composed of six segments following Lawrence (1991). Dorsal length of last abdominal segment (LAS) (measured along midline from anterior to posterior margin). Length of urogomphus (U) was derived by adding the lengths of the individual segments; each segment is denoted by the letter $U$ followed by a number (e.g., U1, first urogomphomere). These measurements were used to calculate several ratios that characterise body shape.

\section{Chaetotaxic analysis}

Primary (present in first-instar larva) and secondary (added in later instars) setae and so-called pores were distinguished on the cephalic capsule, head appendages, legs, last abdominal segment and urogomphus. Sensilla were coded by two capital letters, in most cases corresponding to the first two letters of the name of the structure on which they are located, and a number (setae) or a lower case letter (pores). The following abbreviations were used: $\mathrm{AB}$ - abdominal segment VIII; AN - antenna; $\mathrm{CO}$ - coxa; FE - femur; FR - frontoclypeus; LA - labium; MN - mandible; MX - maxilla; PA - parietal; PT - pretarsus; TA tarsus; TI - tibia; TR - trochanter; UR - urogomphus. Setae and pores present in first-instar larva of $P$. obesus were labelled by comparison with the ground-plan of chaetotaxy of the subfamily Hydroporinae (Alarie \& Harper, 1990; Alarie et al., 1990a; Alarie, 1991a; Alarie \& Michat, 2007a). Homologies were recognised using the criterion of similarity of position (Wiley, 1981). Setae located at the apices of the maxillary and labial palpi were extremely difficult to distinguish due to their position and small size. Accordingly, they are not well represented in the drawings.

\section{Cladistic analysis}

For the study of the phylogenetic relationships of the genus Pachydrus within the subfamily Hydroporinae, P. obesus and 27 other species included in eight of the nine hydroporine tribes were analysed using the parsimony program TNT (Goloboff et al., 2003). The tribe Carabhydrini was not included because the larva of Carabhydrus Watts, 1978 is unknown. Members of six of the remaining nine dytiscid subfamilies were included as outgroups. All characters were treated as unordered and equally weighted. A heuristic search was implemented using "tree bisection reconnection" as algorithm, with 200 replicates and saving 100 trees per replication (previously setting "hold 20000"). Bremer support values were calculated using the commands "hold 20000", "sub n" and "bsupport", where "n" is the number 


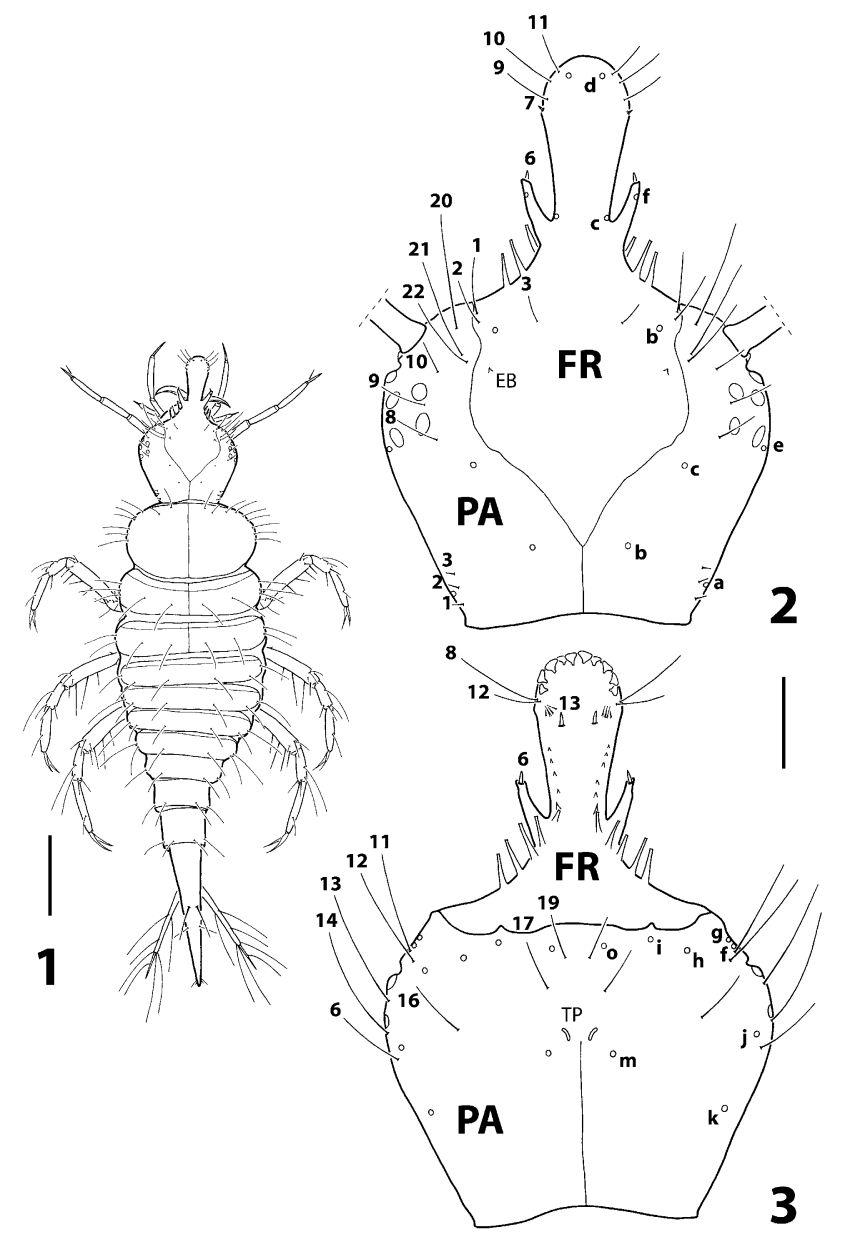

Figs 1-3. Pachydrus obesus, first-instar larva. 1 - habitus, dorsal aspect; 2-3 - cephalic capsule, dorsal and ventral aspects, respectively. EB - egg burster; TP - tentorial pit. Scale bars $=0.30 \mathrm{~mm}(1)$, and $0.10 \mathrm{~mm}(2-3)$.

of extra steps allowed. The process was repeated increasing the length of the suboptimal cladograms by one step, until all Bremer values were obtained (Kitching et al., 1998). Jackknife values were calculated with 2000 replicates and P (removal probability) $=36$.

\section{RESULTS}

\section{Description of the larvae of Pachydrus obesus Sharp, 1882}

Diagnosis

Larvae of Pachydrus are characterised by the following combination of characters: head capsule without neck constriction and occipital suture; nasale strongly elongate, parallel sided, with well developed lateral branches; basoventral surface of nasale with a row of well developed spinulae on each side; A3 without ventroapical spinula; cardo fused to stipes; galea minute; prementum subquadrate, without lateral spinulae; LP2 narrowing abruptly at distal fourth; abdominal segment VI completely sclerotised, ring-like; siphon elongate, subconical, sharp apically; U2 slender, setiform; seta FR7 short, spiniform; pore PAd absent; pore PAc located on basal half of PA; pore ANh absent; setae MX4 and MX10 absent; setae MX8 and MX9 present; pore MXh absent;
TABLE 1. Measurements and ratios for the three larval instars of Pachydrus obesus.

\begin{tabular}{lccc}
\hline Measure & $\begin{array}{c}\text { Instar I } \\
(\mathrm{n}=3)\end{array}$ & $\begin{array}{c}\text { Instar II } \\
(\mathrm{n}=2)\end{array}$ & $\begin{array}{c}\text { Instar III } \\
(\mathrm{n}=3)\end{array}$ \\
\hline TL $(\mathrm{mm})$ & $2.00-2.70$ & $2.90-3.80$ & $4.80-5.20$ \\
MW (mm) & $0.50-0.60$ & $0.80-0.90$ & $1.30-1.50$ \\
HL (mm) & $0.60-0.61$ & $0.78-0.80$ & $1.02-1.07$ \\
HW (mm) & $0.40-0.42$ & $0.58-0.60$ & $0.80-0.81$ \\
FRL (mm) & $0.53-0.54$ & $0.67-0.68$ & $0.88-0.92$ \\
OCW (mm) & $0.21-0.23$ & $0.41-0.42$ & $0.50-0.53$ \\
HL/HW & $1.46-1.50$ & 1.33 & $1.29-1.33$ \\
HW/OCW & $1.79-1.90$ & $1.40-1.47$ & $1.52-1.58$ \\
COL/HL & $0.10-0.12$ & $0.13-0.15$ & $0.14-0.15$ \\
FRL/HL & $0.88-0.90$ & $0.85-0.87$ & $0.85-0.86$ \\
A/HW & $1.11-1.15$ & $0.90-0.93$ & $0.79-0.83$ \\
A3/A1 & $1.50-1.57$ & $1.36-1.41$ & $0.95-1.05$ \\
A3/A2 & $1.22-1.36$ & $1.19-1.22$ & $0.95-1.05$ \\
A4/A3 & $0.33-0.44$ & $0.31-0.34$ & $0.33-0.34$ \\
A3'/A4 & $0.87-0.93$ & $0.85-0.92$ & $0.92-0.93$ \\
MNL/MNW & $4.40-5.50$ & $4.15-4.47$ & $4.48-4.75$ \\
MNL/HL & $0.53-0.54$ & $0.51-0.54$ & $0.51-0.55$ \\
A/MP & $1.24-1.30$ & $1.22-1.24$ & $1.14-1.16$ \\
MP2/MP1 & $1.31-1.42$ & $1.05-1.08$ & $0.83-0.88$ \\
MP2/MP3 & $2.27-2.43$ & $2.60-3.00$ & $2.42-2.53$ \\
MP/LP & $1.45-1.50$ & $1.41-1.44$ & $1.38-1.46$ \\
LP2/LP1 & $1.22-1.67$ & $0.97-1.07$ & $0.78-0.81$ \\
L3 (mm) & $1.11-1.17$ & $1.49-1.51$ & $2.01-2.07$ \\
L3/L1 & $1.11-1.13$ & $1.13-1.15$ & $1.16-1.19$ \\
L3/L2 & $1.08-1.09$ & $1.09-1.11$ & $1.12-1.13$ \\
L3/HW & $2.81-2.82$ & $2.47-2.55$ & $2.50-2.55$ \\
L3 (CO/FE) & $1.04-1.07$ & $1.04-1.06$ & $1.03-1.11$ \\
L3 (TI/FE) & $0.51-0.54$ & $0.47-0.48$ & $0.42-0.45$ \\
L3 (TA/FE) & $0.84-0.86$ & $0.72-0.74$ & $0.57-0.61$ \\
L3 (CL/TA) & $0.47-0.50$ & $0.41-0.43$ & $0.37-0.41$ \\
LAS (mm) & 0.63 & $0.75-0.80$ & $0.97-1.01$ \\
LAS/HW & $1.52-1.58$ & $1.29-1.32$ & $1.21-1.25$ \\
U (mm) & $0.49-0.50$ & $0.50-0.51$ & $0.42-0.48$ \\
U/LAS & $0.77-0.80$ & $0.63-0.68$ & $0.43-0.47$ \\
U/HW & $1.17-1.20$ & $0.84-0.87$ & $0.52-0.59$ \\
U1/U2 & $2.16-2.27$ & $1.73-1.78$ & $1.33-1.69$ \\
\hline & & &
\end{tabular}

seta LA1 absent; seta LA8 dorsoproximal; pore LAb absent; pore COa absent; seta TR2 absent; pore FEa absent; setae FE2, FE5 and FE6 inserted more proximally; seta TI2 elongate, setiform on L2 and L3, short, spiniform on L1; seta TI7 elongate, setiform; FE with anteroventral natatory setae (instars II-III); pores $\mathrm{ABa}$ and $\mathrm{ABd}$ absent; sensillum $\mathrm{AB} 2$ pore-like; seta AB10 spiniform; ventral surface of siphon with setiform secondary setae; setae UR2 and UR3 arising contiguously; seta UR8 inserted on basal third to basal half of U2; U with 1-3 basal, spiniform, secondary setae (instar III).

\section{Instar I}

Colour. Cephalic capsule with dorsal colour pattern composed of a testaceous to light brown background and several brown maculae centrally on FR and on posterior two-third of PA; head appendages testaceous to light brown except for $\mathrm{MN}$ light brown; thoracic and abdominal sclerites $\mathrm{I}-\mathrm{V}$ with colour pattern composed of 


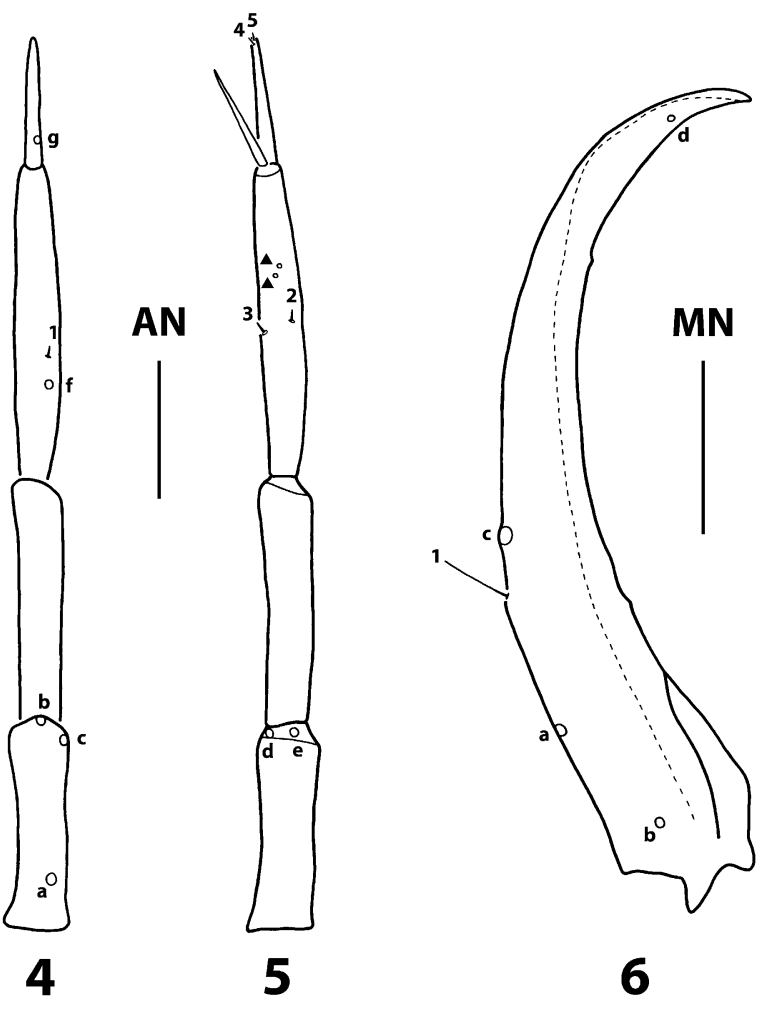

Figs 4-6. Pachydrus obesus, first-instar larva. 4-5 - antenna, dorsal and ventral aspects, respectively; 6 - mandible, dorsal aspect. Solid triangle refers to additional pore. Scale bars $=0.07$ $\mathrm{mm}$.

a testaceous to light brown background and brown maculae; abdominal sclerites VI-VIII evenly light brown, distal portion of segment VIII somewhat darker; membranous parts testaceous; legs and U light brown.

Body. Subcylindrical, narrowing towards abdominal apex (Fig. 1). Measurements and ratios that characterise the body shape are shown in Table 1.

Head. Head capsule (Figs 2-3). Longer than broad; surface with reticulation; basal half (excluding nasale) subovate, maximum width at stemmata, progressively narrowing towards the occipital foramen, without neck constriction; occipital suture absent; ecdysial line well marked, coronal line short; occipital foramen broadly emarginate ventrally; posterior tentorial pits visible ventrally; FR elongate, subtriangular, slightly convex, lateral margins sinuate, with 2 lateral spiniform egg bursters on anterior third; nasale strongly elongate, parallel sided, rounded apically, with well developed lateral branches; lateroventral surface of nasale with a row of short stout spinulae distal to the lateral branches, and a group of slender pointed spinulae near seta FR13; lateroventral surface of nasale also with a row of robust, elongate, apically truncate spinulae beginning at the base and ending at the level of the lateral branches (Fig. 3); anteroventral margin of nasale with a half circle of 10 short spatulate setae directed downwards, the two anteromedial ones somewhat longer than the others; six subequal lateral stemmata on each side, the four dorsal ones forming a square, the two ventral ones displaced anteriorly with
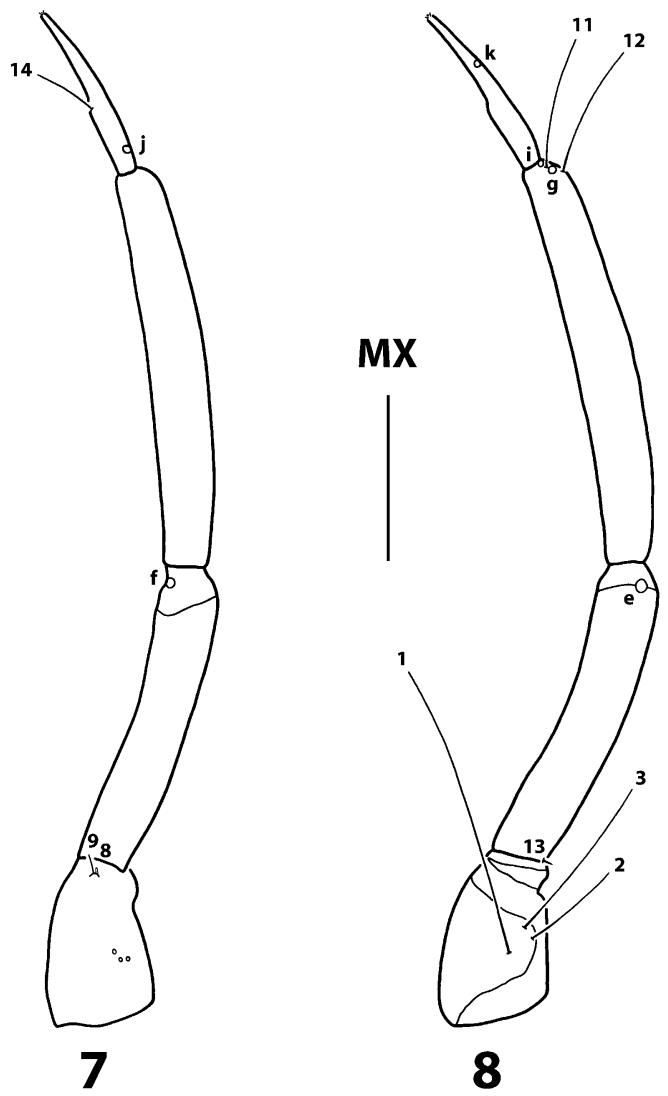

Figs 7-8. Pachydrus obesus, first-instar larva, maxilla, dorsal and ventral aspects, respectively. Scale bar $=0.07 \mathrm{~mm}$.

respect to the others. Antenna (Figs 4-5). Elongate, 4-segmented, somewhat longer than HW; A4 the shortest, A3 the longest, without ventroapical spinula; A3' elongate. Mandible (Fig. 6). Prominent, slender, obliquely oriented, distal half strongly curved inwards and upwards, apex sharp; mandibular channel present. Maxilla (Figs 7-8). Cardo fused to stipes; stipes short, broad, incompletely sclerotised; galea minute; lacinia absent; MP elongate, 3-segmented; MP3 the shortest, MP2 the longest. Labium (Figs 9-10). Prementum subquadrate, about as long as broad, without lateral spinulae; LP elongate, 2-segmented; LP2 longer than LP1, narrowing abruptly on distal fourth.

Thorax. Terga convex, pronotum somewhat shorter than meso- and metanotum combined; meso- and metanotum subequal, wider than pronotum; protergite subovate to subquadrate, margins rounded, more developed than meso- and metatergite; meso- and metatergite transverse, with anterior transverse carina; sagittal line visible on the three tergites; sterna membranous; spiracles absent. Legs (Figs 11-12). Long, 6-segmented; L1 the shortest, L3 the longest; CO robust, elongate, TR divided into 2 parts, FE, TI and TA slender, subcylindrical, PT with 2 long, slender, slightly curved claws; posterior claw shorter than anterior one on L1 and L2, claws subequal in length on L3; surface of TR, FE, TI and TA covered in part with minute spinulae, TI and TA with a ventral row of elongate spinulae. 


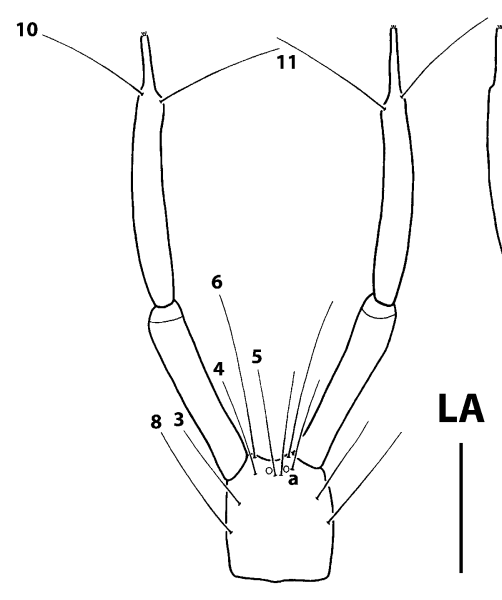

9

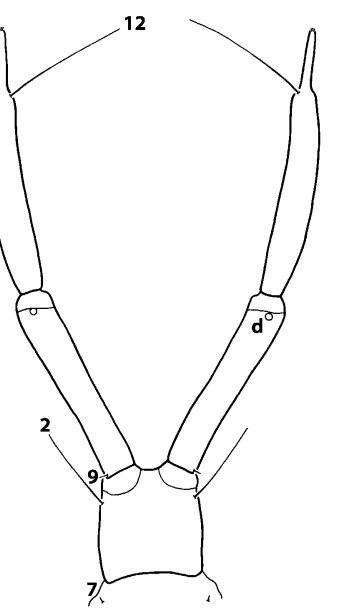

10
Figs 9-10. Pachydrus obesus, first-instar larva, labium, dorsal and ventral aspects, respectively. Scale bar $=0.07 \mathrm{~mm}$.

Abdomen. Eight-segmented; segments I-V sclerotised dorsally, membranous ventrally, segments VI-VII completely sclerotised, ring-like; tergites I-VI similar to each other, narrow, transverse; segment VII somewhat longer; spiracles absent on segments I-VII; LAS (Figs 13-14) the longest, completely sclerotised, ring-like; all sclerites with anterior transverse carina, without sagittal line, covered with slender spinulae in transverse rows; siphon elongate, subconical, sharp apically. Urogomphus (Fig. 15). Elongate, 2-segmented; U1 shorter than siphon; U2 slender, setiform, shorter than U1.

Chaetotaxy (Figs 1-15). Similar to that of generalised Hydroporinae larva (Alarie, 1991a; Alarie \& Harper, 1990; Alarie et al., 1990a; Alarie \& Michat, 2007a) except for the following features: seta FR7 short, spiniform; seta FR13 inserted distally on the nasale; pore PAd absent; pore PAb located basally; pore PAc located on basal half of PA; pore PAg present; pore ANh absent; A3 with two minute structures (possibly additional pores) on ventral surface; seta MX1 inserted on the stipes; setae MX4 and MX10 absent; setae MX5, MX6 and MX7 absent (however, three vestigial structures are present where these setae are commonly located, suggesting that the setae were lost secondarily); setae MX8 and MX9 present; pore MXh absent; seta LA1 absent; seta LA2 inserted marginally; seta LA8 dorsoproximal; pore LAb absent; setae LA10, LA11 and LA12 elongate; pore COa absent; pore COd located more proximally; seta $\mathrm{CO} 12$ setiform; seta TR2 absent; pore FEa absent; setae FE2, FE5 and FE6 inserted more proximally; setae FE8 and FE9 elongate; seta TI2 elongate, setiform on L2 and L3, short, spiniform on L1; seta TI7 elongate, setiform; seta TA7 elongate, setiform; the naming of setae and pores on the siphon should be considered tentative, since homologies were difficult to establish due to the different shapes of this structure within Hydroporinae; pores $\mathrm{ABa}$ and ABd absent; sensillum AB2 pore-like; seta AB3 strongly developed, spiniform; seta AB8 minute; seta AB10 spiniform; setae UR2 and UR3 arising contiguously; seta UR5 elongate, setiform; seta UR8 inserted on basal third to basal half of $\mathrm{U} 2$.

\section{Instar II}

As first-instar larva except for the following features. Colour. Distal portion of segment VIII of similar colour as the rest of the segment. Body. Measurements and ratios that characterise the body shape are shown in Table 1. Head. Head capsule. Basal half (excluding nasale) subquadrate; anteroventral margin of nasale with 20-21 short spatulate setae. Antenna. Somewhat shorter than HW. Maxilla. MP1 and MP2 the longest, subequal. Labium. LP1 and LP2 subequal in length. Thorax. Legs. Spinulae restricted to ventral surface of FE, TI and TA, rows on TI and TA elongate. Chaetotaxy. Head capsule with numerous minute or setiform secondary setae, and

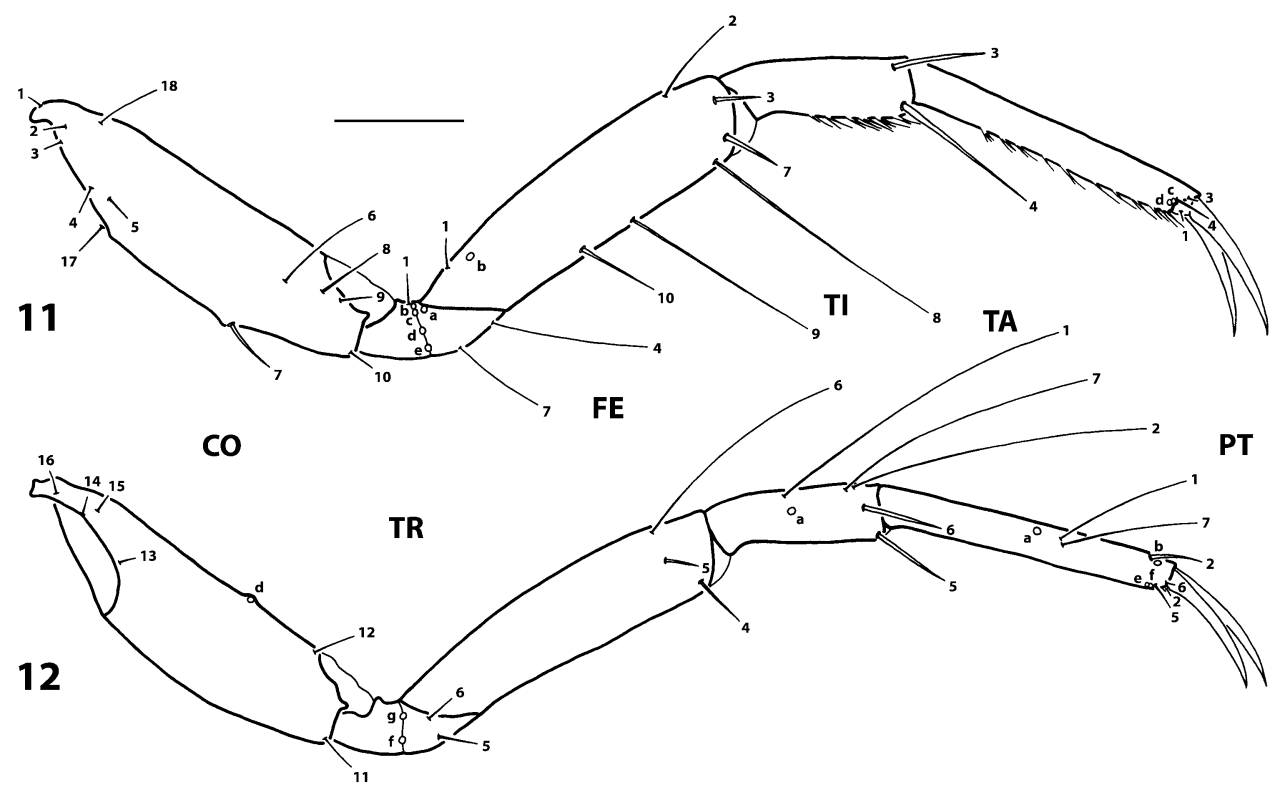

Figs 11-12. Pachydrus obesus, first-instar larva, metathoracic leg, anterior and posterior aspects, respectively. Scale bar $=0.10$ $\mathrm{mm}$. 

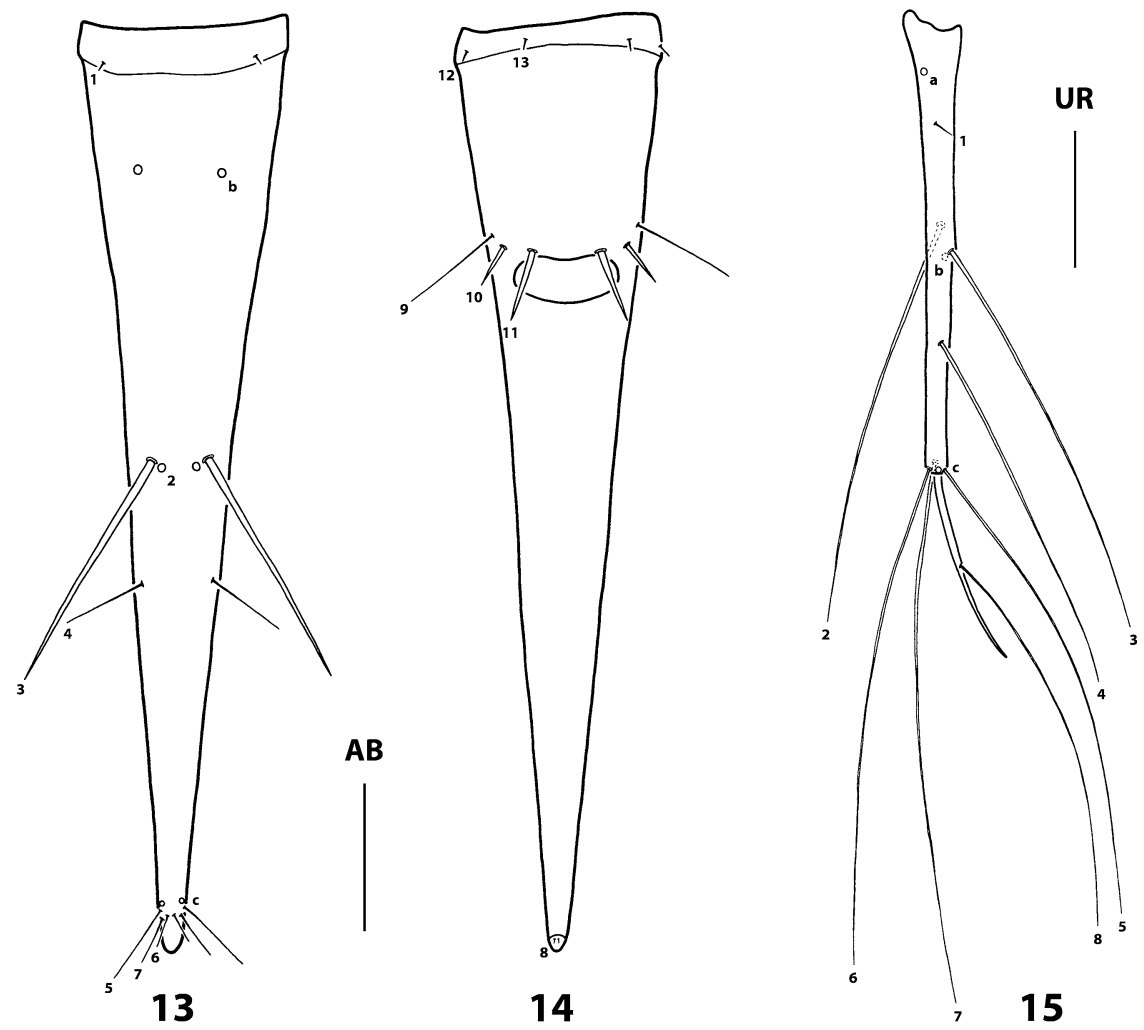

Figs 13-15. Pachydrus obesus, first-instar larva. 13-14 - abdominal segment VIII, dorsal and ventral aspects, respectively; 15 urogomphus, dorsal aspect. Scale bars $=0.10 \mathrm{~mm}$.

7-8 spiniform secondary setae on each lateral margin of PA; MN with 1 setiform secondary seta on basoexternal margin; prementum with one secondary seta on each lateral margin; thoracic tergites with numerous setiform secondary setae; secondary leg setation detailed in Table 2; FE with a row of natatory setae on anteroventral margin; abdominal sclerites I-VIII with numerous setiform secondary setae; ventral surface of siphon with several setiform secondary setae.

Instar III

As second-instar larva except for the following features. Colour. Colour pattern more diffusely delimited. Body. Measurements and ratios that characterise the body shape are shown in Table 1. Head (Fig. 16). Head capsule. Anteroventral margin of nasale with 42 short spatulate setae. Antenna. A1, A2 and A3 the longest, subequal. Maxilla. MP1 the longest. Labium. LP1 longer than LP2. Thorax. Spiracles present on mesothorax. Legs. Spinulae absent on meso- and metaFE. Abdomen. Spiracles present on segments I-VII, those on segments V-VII very small, indistinct. Chaetotaxy. PA with 9-11 spiniform secondary setae on each lateral margin; secondary leg setation detailed in Table 2 and Figs 17-18; secondary setation on LAS and U detailed in Fig. 19; U with 1-3 basal, spiniform, secondary setae.

\section{Comparative notes}

The third-instar larva of $P$. obesus described here is very similar morphometrically to that described by Crespo (1996). The seta TR2 and the pore FEa, reported as absent by Crespo (1996) are also absent in our material. However, Crespo (1996) reported the absence of pore URc. This pore is present in our larvae, located terminally on the dorsal surface of the first urogomphomere. Due to the terminal location of URc, and the presence of setae on that region of the urogomphus, this pore is difficult to see and may be easily overlooked.

The descriptions of Bertrand (1968) and Spangler \& Folkerts (1973) are superficial, making in-depth comparisons with the larvae described here difficult. Nevertheless, $P$. princeps and $P$. obesus seem to be structurally similar. We did not find reliable characters to

TABLE 2. Number and position of secondary setae on the legs of larvae of Pachydrus obesus. Numbers between slash marks refer to pro-, meso- and metathoracic legs, respectively. A anterior, $\mathrm{D}$ - dorsal, $\mathrm{P}$ - posterior, $\mathrm{Pr}$ - proximal, $\mathrm{V}$ - ventral, Total - total number of secondary setae on the segment (excluding primary and natatory setae).

\begin{tabular}{llll}
\hline Segment & Position & Instar II $(\mathrm{n}=2)$ & Instar III $(\mathrm{n}=3)$ \\
\hline Coxa & PD & $4 / 3-4 / 2-4$ & $5-7 / 5-8 / 4-6$ \\
\multirow{5}{*}{ Trochanter } & Total & $4 / 3-4 / 2-4$ & $5-7 / 5-8 / 4-6$ \\
& Pr & $1 / 1 / 1$ & $1 / 1 / 1-2$ \\
Femur & Total & $1 / 1 / 1$ & $1 / 1 / 1-2$ \\
& AV & $0 / 4 / 3-6$ & $0-1 / 10-15 / 11-13$ \\
& PV & $2 / 4 / 5-6$ & $7-10 / 9-10 / 10-12$ \\
Tibia & Total & $2 / 8 / 8-12$ & $7-10 / 20-24 / 21-24$ \\
\multirow{4}{*}{ Tarsus } & AV & $2 / 3-4 / 4$ & $2-3 / 5-6 / 6-7$ \\
& Total & $2 / 3-4 / 4$ & $2-3 / 5-6 / 6-7$ \\
& AV & $5 / 4-6 / 5-6$ & $5-7 / 5-7 / 6-8$ \\
& Total & $5 / 4-6 / 5-6$ & $5-7 / 5-7 / 6-8$ \\
\hline
\end{tabular}




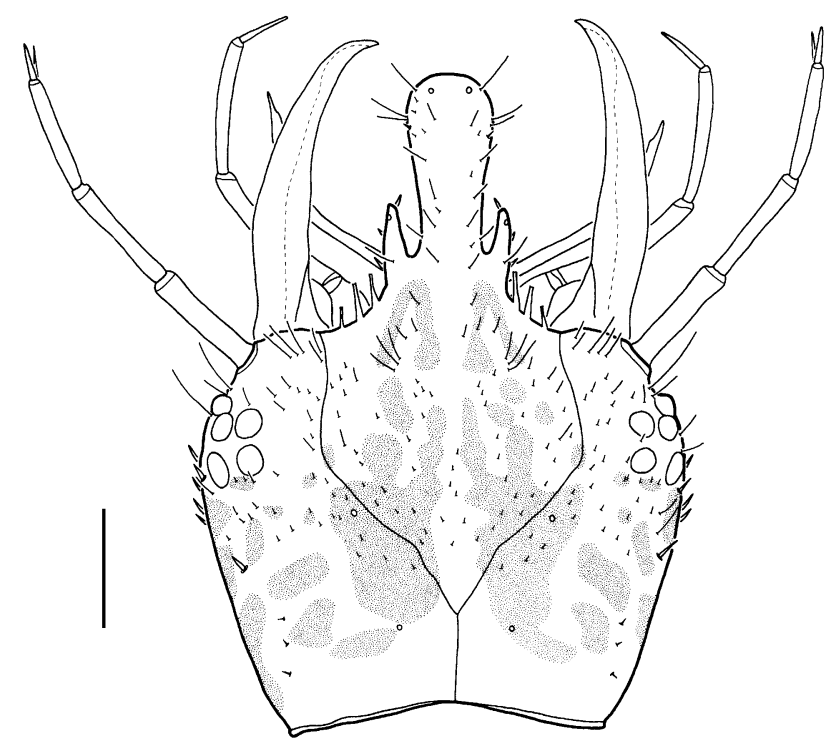

Fig. 16. Pachydrus obesus, third-instar larva, head, dorsal aspect. Scale bar $=0.20 \mathrm{~mm}$.

separate these species. In their description of $P$. princeps, Spangler \& Folkerts (1973) report the presence of 4-segmented maxillary palpi, 3-segmented labial palpi and 1-segmented urogomphi. In P. obesus, the maxillary palpi are 3-segmented, the labial palpi are 2-segmented, and the urogomphi are 2-segmented. The characteristics observed in P. obesus are common within the subfamily Hydroporinae (Bertrand, 1972; Alarie \& Delgado, 1999; Michat \& Torres, 2005). Based on this evidence and the drawings of Spangler \& Folkerts (1973), it is likely that the whole stipes was considered as a palpomere, the distal constriction of the second labial palpomere was interpreted as an articulation and the second urogomphomere was overlooked.

According to Alarie \& Megna (2006) third-instar larvae of $P$. globosus and $P$. obniger are very similar morphologically, and no differences were found to separate them. The third instar of $P$. obesus is also very similar to those of $P$. globosus and $P$. obniger, in morphometry as well as chaetotaxy, suggesting a marked structural homogeneity within the genus. The seta identified as LA1 in P. globosus (Alarie et al., 1997) is secondary in P. obesus. Alarie et al. (1997) and Alarie \& Megna (2006) report the absence of secondary setae on the ventral surface of the siphon in $P$. globosus and $P$. obniger. These setae are present in $P$. obesus, which may constitute a diagnostic difference. However, we have not seen material of $P$. globosus and $P$. obniger, so these setae may have been overlooked.

\section{Character analysis}

One hundred and twenty-two characters (100 binary and 22 multistate) were coded for larvae of 28 species of Hydroporinae and six outgroups (Table 3 ). The characters used and their states are listed in Appendix 1. The analysis of the data matrix (Appendix 2) using TNT resulted in 13 most parsimonious cladograms of length 350. In all trees, Pachydrus was resolved as the sister

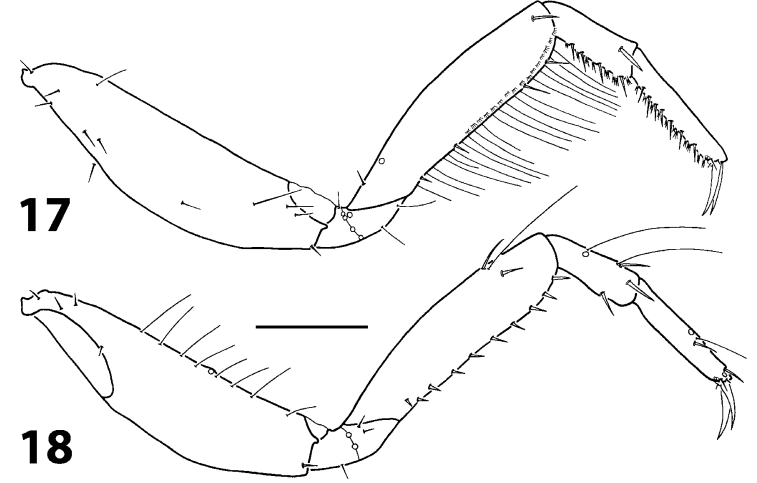

Figs 17-18. Pachydrus obesus, third-instar larva, prothoracic leg, anterior and posterior aspects, respectively. Scale bar $=0.20$ $\mathrm{mm}$.

group of Hydrovatus Motschulsky, 1853. The trees differed largely in outgroup topology and/or in the relative positions of several Hydroporini genera. For this reason, the strict consensus was calculated, in which several taxa collapsed in polytomies (Fig. 20). In the consensus, the clade Hyphydrini minus Pachydrus was recovered as monophyletic and well supported, as part of a polytomy along with Vatellini and the genus Antiporus Sharp, 1882 (Hydroporini), whereas Pachydrus was recovered as sister to Hydrovatus, and more closely related to Canthyporus Zimmermann, 1919, Laccornellus Roughley \& Wolfe, 1987 and Laccornis Gozis, 1914 than to other Hyphydrini genera. Characters of interest were mapped (using ACCTRAN optimization) in one of the most parsimonious cladograms (Fig. 21). The support obtained was

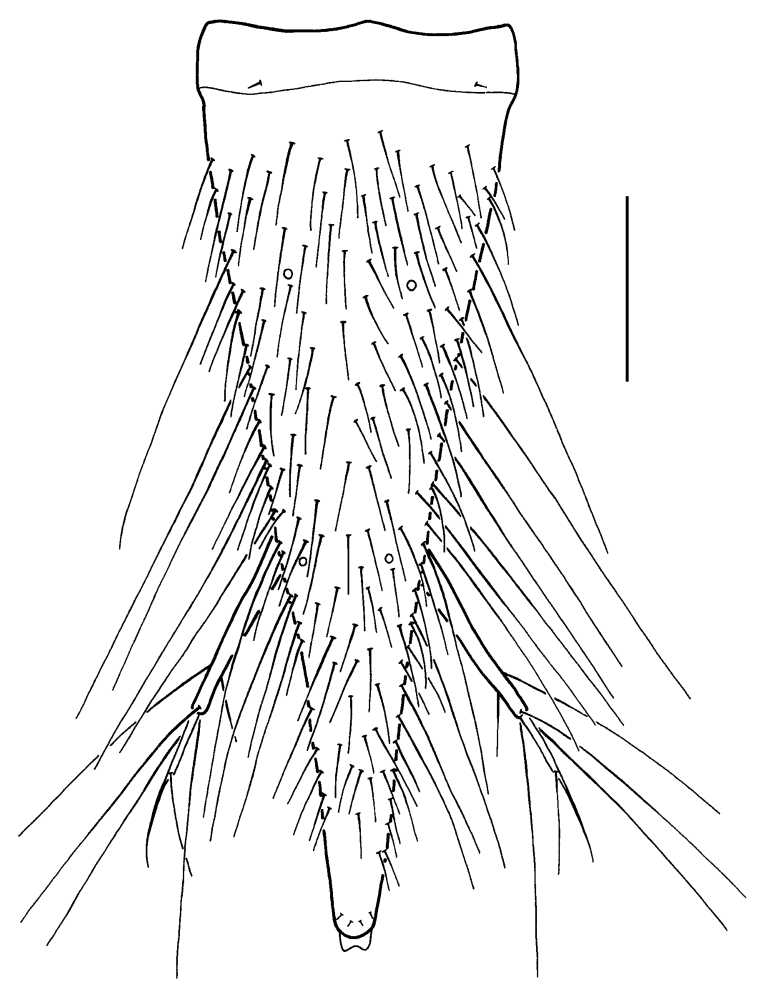

Fig. 19. Pachydrus obesus, third-instar larva, abdominal segment VIII and urogomphi, dorsal aspect. Scale bar $=0.20 \mathrm{~mm}$. 
TABLE 3. Taxa coded for parsimony analysis.

\begin{tabular}{|c|c|c|}
\hline Taxon & Species & Source \\
\hline \multicolumn{3}{|l|}{ AGABINAE } \\
\hline Agabini & Agabus anthracinus Mannerheim, 1852 & Alarie $(1995,1998)$ \\
\hline \multicolumn{3}{|c|}{ COLYMBETINAE } \\
\hline Colymbetini & Rhantus signatus (Fabricius, 1775) & M.C. Michat collection \\
\hline \multicolumn{3}{|c|}{ DytisCINAE } \\
\hline Hydaticini & Hydaticus tuyuensis Trémouilles, 1996 & Michat \& Torres (2006a) \\
\hline \multicolumn{3}{|c|}{ HYDROPORINAE } \\
\hline \multirow[t]{4}{*}{ Bidessini } & Amarodytes duponti (Aubé, 1838) & Michat \& Alarie (2006) \\
\hline & Anodocheilus maculatus Babington, 1841 & Michat \& Torres (2006b) \\
\hline & Hypodessus cruciatus (Régimbart, 1903) & Michat \& Alarie (2008) \\
\hline & Liodessus flavofasciatus (Steinheil, 1869) & Alarie et al. (2007) \\
\hline \multirow[t]{11}{*}{ Hydroporini } & Antiporus uncifer Sharp, 1882 & Alarie \& Watts (2004) \\
\hline & Canthyporus kenyensis Bilardo \& Sanfilippo, 1979 & Shaverdo \& Alarie (2006) \\
\hline & Deronectes latus (Stephens, 1829) & Alarie et al. (1999) \\
\hline & Heterosternuta wickhami (Zaitzev, 1908) & Alarie \& Harper (1990); Alarie et al. (1990a); Alarie (1991a, b) \\
\hline & Hydrocolus paugus (Fall, 1923) & Alarie \& Harper (1990); Alarie et al. (1990a); Alarie (1991a, b) \\
\hline & Hydroporus columbianus Fall, 1923 & Alarie \& Harper (1990); Alarie et al. (1990a); Alarie (1991a, b) \\
\hline & Laccornellus lugubris (Aubé, 1838) & Alarie \& Michat (2007b) \\
\hline & Neoporus undulatus (Say, 1823) & Alarie \& Harper (1990); Alarie et al. (1990a); Alarie (1991a, b) \\
\hline & Oreodytes scitulus (LeConte, 1855) & Alarie (1997) \\
\hline & Scarodytes halensis (Fabricius, 1787) & Alarie et al. (1999) \\
\hline & Stictonectes canariensis Machado, 1987 & Alarie \& Nilsson (1997) \\
\hline Hydrovatini & Hydrovatus caraibus Sharp, 1882 & Michat (2006) \\
\hline \multirow[t]{3}{*}{ Hygrotini } & Coelambus impressopunctatus (Schaller, 1783) & Alarie \& Harper (1990); Alarie et al. (1990a, b); Alarie (1991a) \\
\hline & Herophydrus musicus (Klug, 1834) & Alarie et al. (2001a) \\
\hline & Hygrotus sayi J. Balfour-Browne, 1944 & Alarie \& Harper (1990); Alarie et al. (1990a, b); Alarie (1991a) \\
\hline \multirow[t]{6}{*}{ Hyphydrini } & Andex insignis Sharp, 1882 & Alarie \& Challet (2006b) \\
\hline & Desmopachria concolor Sharp, 1882 & Michat \& Archangelsky (2007) \\
\hline & Desmopachria punctatissima Zimmermann, 1923 & Michat \& Archangelsky (2007) \\
\hline & Hyphydrus ovatus (Linnaeus, 1761) & Alarie et al. (1997) \\
\hline & Microdytes uenoi Satô, 1972 & Alarie et al. (1997) \\
\hline & Pachydrus obesus Sharp, 1882 & This paper \\
\hline Laccornini & Laccornis latens (Fall, 1937) & $\begin{array}{l}\text { Alarie \& Harper (1990); Alarie et al. (1990a); Alarie (1989, } \\
\text { 1991a) }\end{array}$ \\
\hline Methlini & Celina parallela (Babington, 1841) & Michat et al. (2007) \\
\hline Vatellini & Vatellus haagi Wehncke, 1876 & Michat \& Torres (2005) \\
\hline \multicolumn{3}{|l|}{ LACCOPHILINAE } \\
\hline Laccophilini & Laccophilus maculosus Say, 1823 & Alarie et al. (2000) \\
\hline \multicolumn{3}{|c|}{ LANCETINAE } \\
\hline Lancetini & Lancetes marginatus (Steinheil, 1869) & Michat et al. (2005) \\
\hline \multicolumn{3}{|l|}{ MATINAE } \\
\hline Matini & Matus bicarinatus (Say, 1823) & Alarie et al. (2001b) \\
\hline
\end{tabular}

variable throughout the tree, with some clades well supported and others showing lower values.

\section{DISCUSSION}

The results of the cladistic analysis are interesting with regard to the phylogenetic position of the genus Pachydrus within Hydroporinae. The analysis supports a polyphyletic origin of the tribe Hyphydrini as long as Pachydrus is included. In fact, whereas Pachydrus appears among the ancestral groups of Hydroporinae, more closely related to Hydrovatini, the clade formed by the remaining Hyphydrini genera appears as monophyletic and well supported (Fig. 20). Though the identity of the sister group of Hyphydrini remains obscure based on the results of this analysis, the tribe apears to be more closely related to Vatellini and the genus Antiporus. The results obtained here are in agreement with previous studies that suggest that Pachydrus is a strange element within the Hyphydrini and may be improperly placed in that tribe (Young, 1980; Biström et al., 1997).

In this study, Hyphydrini (excluding Pachydrus) is well supported and characterised by four apomorphies: absence of pore FRb (character 14.1), pore PAc inserted distally (anterior to the stemmata) (character 19.1), prementum longer than broad (character 55.1) and seta UR8 inserted proximally on second urogomphomere (character 118.3) (Figs 20-21). Hyphydrini is also supported by several homoplastic characters including: absence of pore PAj (character 22.1, homoplastic in Bidessini and Hydrovatus), absence of pore ANh (character 34.1, homoplastic in Pachydrus and Hydrovatus), seta LA8 inserted proximally (character 67.1, homoplastic in Pachydrus and 


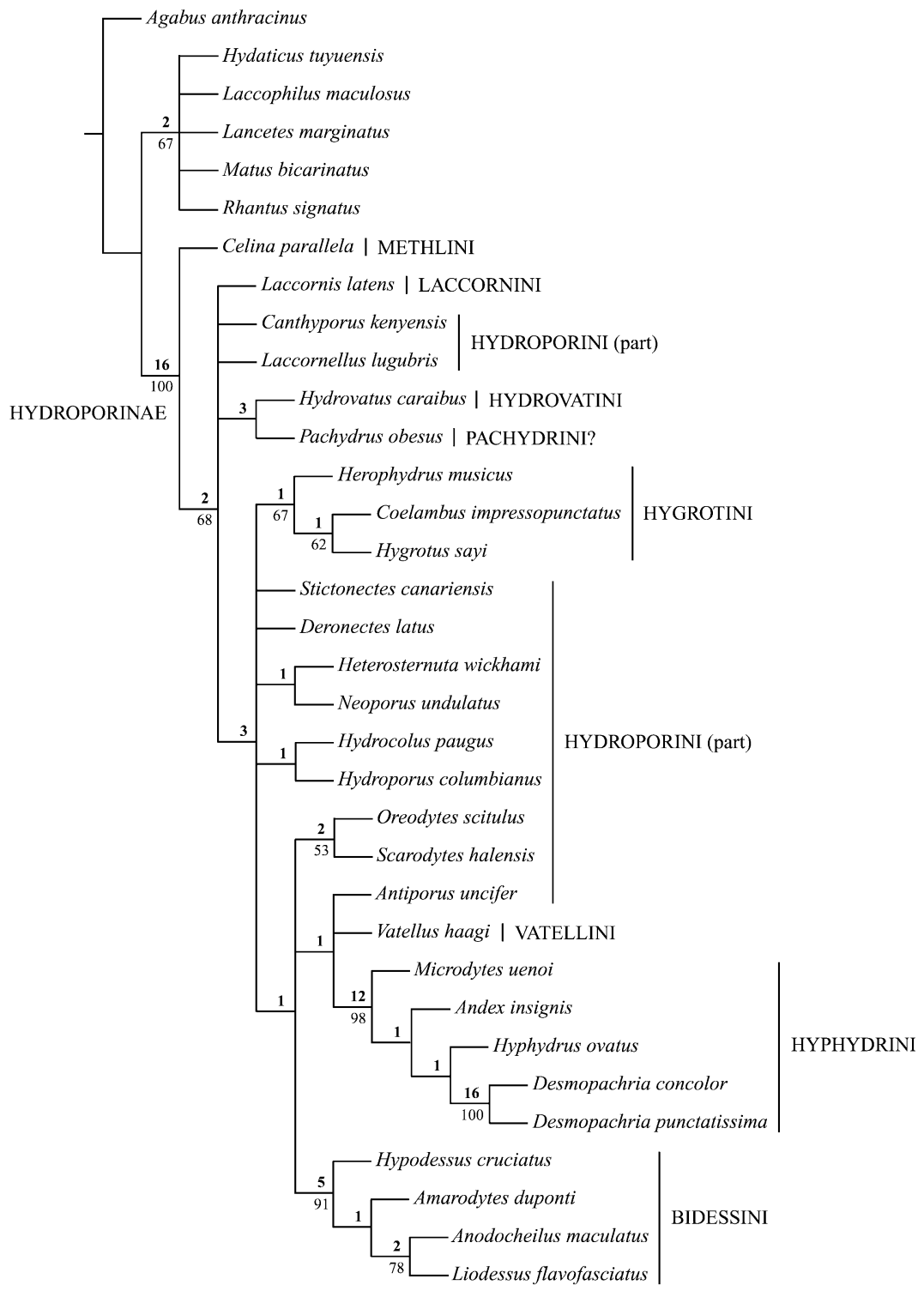

Fig. 20. Strict consensus cladogram of 34 terminal taxa of Dytiscidae. Bremer support values are indicated above branches; jackknife values above 50 are indicated below branches.

Hydrovatus), seta LA12 inserted distally (character 70.1, homoplastic in Pachydrus and Celina Aubé, 1837), ventral surface of abdominal segments IV-V sclerotised in instar III (character 95.1, homoplastic in Hydrovatus), ventral surface of abdominal segment VI sclerotised (character 96.1, homoplastic in Pachydrus and Hydrovatus), sensillum AB2 pore-like (character 102.1, homoplastic in Pachydrus), seta AB5 strongly developed (character 105.1, homoplastic in Canthyporus and Hydrovatus) and seta AB7 well developed (character 107.1, homoplastic in Vatellus Aubé, 1837) (Fig. 21). Characters $14.1,22.1,34.1,96.1$ and 118.3 were previously proposed as synapomorphies for Hyphydrini including Pachydrus by Alarie et al. (1997) and Alarie \& Challet (2006a, b), who also regard the epicranial plates meeting on the ventral midline (a character not included in this study) as synapomorphic. However, as mentioned above, characters $22.1,34.1$ and 96.1 are homoplastic in the cladogram obtained in this study. Only one character, the pore-like aspect of the sensillum AB2 (character 102.1), is shared exclusively by Hyphydrini and Pachydrus and may indicate a closer relationship between these taxa than that hypothesised here.

Pachydrus is a highly distinctive genus within Hydroporinae, characterised by 10 apomorphies: presence of a row of elongate spinulae on basoventrolateral surface of nasale (character 9.1), galea minute (character 42.2), pore MXh absent (character 52.2), seta LA1 absent (character 60.1), pore COa absent (character 75.1), seta FE2 inserted subdistally (character 77.1), presence of natatory ventral setae on femur (character 81.1), seta TI2 elongate, setiform on meso- and metatibia (character 83.1), abdominal segment VII completely sclerotised in instar I (character 97.2) and seta AB3 spiniform (character 103.1) (Fig. 21). It is interesting to note that some of these characters (9.1, $60.1,75.1,77.1$ and 83.1) are not found in any other dytiscid for which the larvae are known in detail, which indicates Pachydrus is a very distinctive diving-beetle 


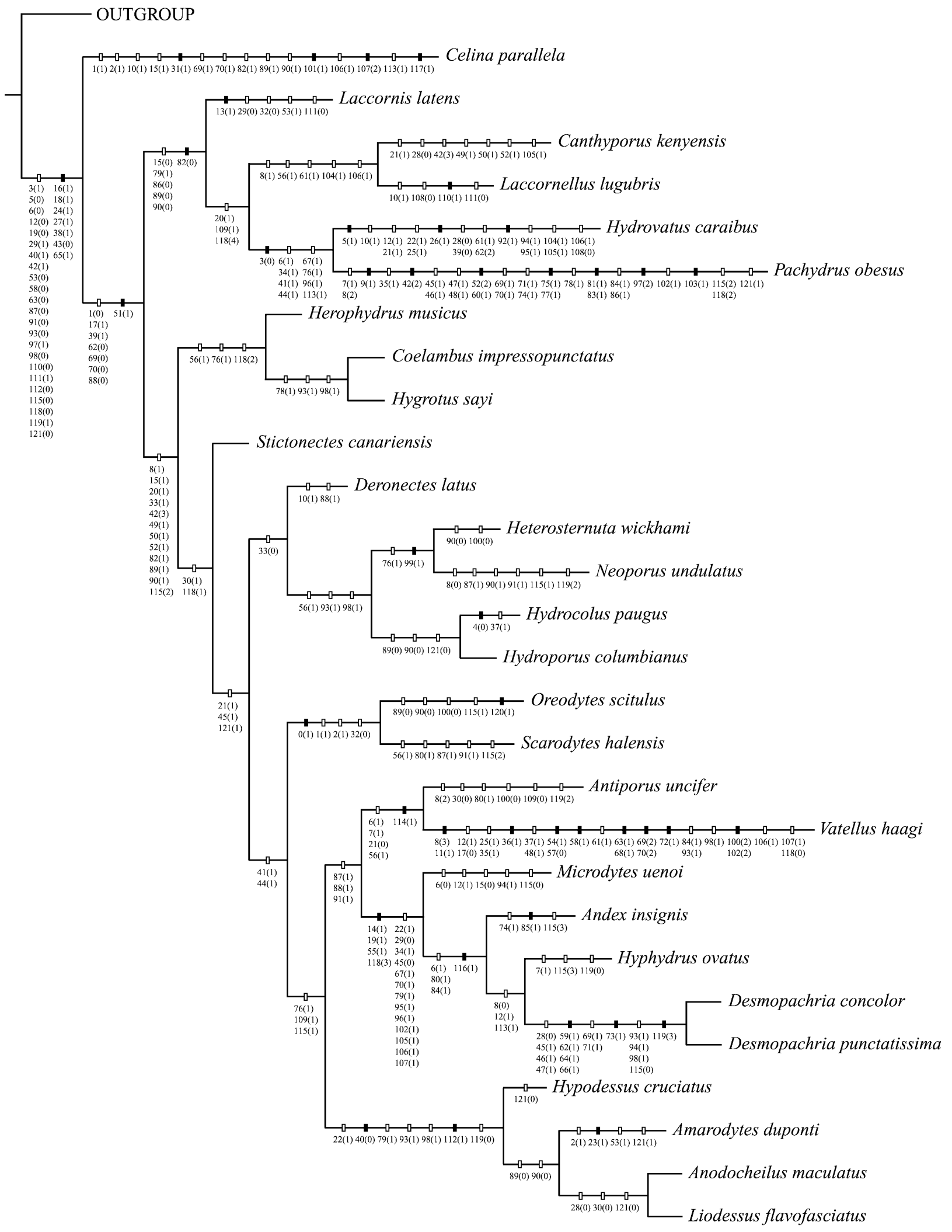

Fig. 21. One of the most parsimonious cladograms of 34 terminal taxa of Dytiscidae, with character changes mapped for the clades of Hydroporinae. Solid rectangles indicate unique character state transformations; open rectangles indicate homoplastic character state transformations.

genus. Pachydrus is resolved as the sister group of Hydrovatini (Fig. 20). Both taxa share a unique character within Hydroporinae: the absence of an occipital suture in instars II and III (character 3.0). As mentioned above, both taxa are characterised by some other characters also present in Hyphydrini (Fig. 21). 
On the basis of the results presented here, the evidence for a monophyletic origin of Hyphydrini excluding Pachydrus is strong. Given that Hyphydrini minus Pachydrus is a highly distinctive group supported by several larval apomorphies, it seems useful to recognise this group as Hyphydrini. Including Pachydrus within Hyphydrini would leave the tribe with a single larval apomorphy (the pore-like aspect of the sensillum AB2), as most characters present in Hyphydrini including Pachydrus are also present in Hydrovatini. Even if future evidence suports that Pachydrus and Hyphydrini are sister groups, as sometimes regarded in the past (Biström et al., 1997; Alarie et al., 1997; Alarie \& Challet, 2006a, b), larval characters argue in favour of a placement of Pachydrus outside the Hyphydrini. These results follow Young (1980) and Biström et al. (1997), who based on adult characters supported the inclusion of Pachydrus in Pachydrini, and contradict the results of Miller (2001) and Miller et al. (2006) based on adults and Alarie et al. (1997) and Alarie \& Challet (2006a, b) based on larvae, who support the inclusion of Pachydrus in Hyphydrini. However, although this study indicates that Pachydrus should be excluded from Hyphydrini, we do not formally propose exclusion at this stage. On the one hand, a placement of Pachydrus within Hydrovatini (a possible scenario based on our results) seems inconvenient given that Hydrovatini as presently conceived is a well defined tribe based on adult morphology (Miller, 2001; Miller et al., 2006). On the other hand, the reinstatement of Pachydrini may be premature in the absence of larvae of Heterhydrus and a more comprehensive study including more species and characters. Therefore, we prefer to formally retain Pachydrus in Hyphydrini (the placement given by Nilsson, 2001) until future analyses, including adult and larval characters as well as molecular data, improve the resolution of the phylogeny under study.

Larval morphology of members of Hyphydrini is in need of further study. The larvae of most genera within the tribe (e.g., Agnoshydrus Biström, Nilsson \& Wewalka, 1997, Allopachria Zimmermann, 1924, Coelhydrus Sharp, 1882, Darwinhydrus Sharp, 1882, Dimitshydrus Uéno, 1996, Hovahydrus Biström, 1982, Hydropeplus Sharp, 1882, Hyphovatus Wewalka \& Biström, 1994) are still unknown, and few species of other, speciose genera (e.g., Desmopachria, Hyphydrus Illiger, 1802, Microdytes J. Balfour-Browne, 1946) are known in detail. In particular, detailed studies (including chaetotaxy) of the larvae of Heterhydrus would be of great interest. With the very deficient knowledge of the larval morphology of Heterhydrus that we have at present (Bertrand, 1972) little can be said about whether larval characters support a close relationship of this genus with Pachydrus or the placement of Heterhydrus within Hyphydrini.

ACKNOWLEDGEMENTS. We thank S.A. Mazzucconi for donation of larval material, and P. Švácha and two anonymous referees for useful comments on the manuscript. Our field and laboratory work was supported in part by grant PIB X846 from the Universidad de Buenos Aires (UBA) and postgraduate scholarships from the Consejo Nacional de Investigaciones Científicas y Técnicas de la República Argentina (CONICET).

\section{REFERENCES}

Alarie Y. 1989: The larvae of Laccornis Des Gozis 1914 (Coleoptera: Adepaga: Dytiscidae) with description of L. latens (Fall, 1937) and redescription of L. conoideus (Leconte, 1850). Coleopt. Bull. 43: 365-378.

Alarie Y. 1991a: Primary setae and pores on the cephalic capsule and head appendages of larval Hydroporinae (Coleoptera: Dytiscidae). Can. J. Zool. 69: 2255-2265.

ALARIE Y. 1991b: Description of larvae of 17 Nearctic species of Hydroporus Clairville (Coleoptera: Dytiscidae: Hydroporinae) with an analysis of their phylogenetic relationships. Can. Entomol. 123: 627-704.

Alarie Y. 1995: Primary setae and pores on the legs, the last abdominal segment, and the urogomphi of larvae of Nearctic Colymbetinae (Coleoptera: Adephaga: Dytiscidae) with an analysis of their phylogenetic relationships. Can. Entomol. 127: 913-943.

AlARIE Y. 1997: Taxonomic revision and phylogenetic analysis of the genus Oreodytes Seidlitz (Coleoptera: Dytiscidae: Hydroporinae) based on larval morphology. Can. Entomol. 129: 399-503.

ALARIE Y. 1998: Phylogenetic relationships of Nearctic Colymbetinae (Coleoptera: Adephaga: Dytiscidae) based on chaetotaxic and porotaxic analysis of head capsule and appendages of larvae. Can. Entomol. 130: 803-824.

Alarie Y. \& Challet G.L. 2006a: Description of the larva of Primospes suturalis Sharp (Coleoptera: Dytiscidae, Hydroporinae) with implications for the phylogeny of the Hyphydrini. Aquat. Insects 28: 31-46.

Alarie Y. \& Challet G.L. 2006b: Larval description and phylogenetic placement of the South African endemic genus Andex Sharp (Coleoptera: Adephaga: Dytiscidae). Ann. Entomol. Soc. Am. 99: 743-754.

Alarie Y. \& Delgado J.A. 1999: Study of the larvae of Antiporus strigosulus (Broun) (Coleoptera: Dytiscidae) with implications for the phylogeny of the Hydroporini. Aquat. Insects 21: 99-113.

Alarie Y. \& HarPer P.P. 1990: Primary setae and pores on the last abdominal segment and the urogomphi of larval Hydroporinae (Coleoptera: Adephaga: Dytiscidae), with notes on other dytiscid larvae. Can. J. Zool. 68: 368-374.

Alarie Y. \& Megna Y.S. 2006: Description of the larva of Cuban specimens of Pachydrus obniger (Chevrolat, 1863) (Coleoptera: Dytiscidae). Koleopt. Rdsch. 76: 43-49.

Alarie Y. \& Michat M.C. 2007a: Primary setae and pores on the maxilla of larvae of the subfamily Hydroporinae (Coleoptera: Adephaga: Dytiscidae): ground plan pattern reconsidered. Coleopt. Bull. 61: 310-317.

Alarie Y. \& Michat M.C. 2007b: Phylogenetic analysis of Hydroporinae (Coleoptera: Dytiscidae) based on larval morphology, with description of first instar of Laccornellus lugubris. Ann. Entomol. Soc. Am. 100: 655-665.

Alarie Y. \& Nilsson A.N. 1997: Larvae of Stictonectes Brinck: generic characteristics, description of S. canariensis Machado, and analysis of phylogenetic relationships with other genera of the tribe Hydroporini (Coleoptera: Dytiscidae). Coleopt. Bull. 51: 120-139.

Alarie Y. \& WatTs C.H.S. 2004: Larvae of the genus Antiporus (Coleoptera: Dytiscidae) and phylogenetic implications. Invert. Syst. 18: 523-546. 
Alarie Y., Harper P.P. \& Maire A. 1990a: Primary setae and pores on legs of larvae of Nearctic Hydroporinae (Coleoptera: Dytiscidae). Quaest. Entomol. 26: 199-210.

Alarie Y., Harper P.P. \& Roughley R.E. 1990b: Description of the larvae of eleven Nearctic species of Hygrotus Stephens (Coleoptera: Dytiscidae: Hydroporinae) with an analysis of their phyletic relationships. Can. Entomol. 122: 985-1035.

Alarie Y., Wang L.J., Nilsson A.N. \& Spangler P.J. 1997: Larval morphology of four genera of the tribe Hyphydrini Sharp (Coleoptera: Dytiscidae: Hydroporinae) with an analysis of their phylogenetic relationships. Ann. Entomol. Soc. Am. 90: 709-735.

Alarie Y., Nilsson A.N. \& Hendrich L. 1999: Larval morphology of the palearctic genera Deronectes Sharp and Scarodytes Gozis (Coleoptera: Dytiscidae: Hydroporinae), with implications for the phylogeny of the Deronectes-group of genera. Entomol. Scand. 30: 178-195.

Alarie Y., Nilsson A.N., Hendrich L. \& Watts C.H.S. 2000: Larval morphology of four genera of Laccophilinae (Coleoptera: Adephaga: Dytiscidae) with an analysis of their phylogenetic relationships. Insect Syst. Evol. 31: 121-164.

Alarie Y., Cuppen J.G.M., Hendrich L. \& Nilsson A.N. 2001a: Description of larvae of Herophydrus musicus (Klug) and analysis of relationships with members of the genus Hygrotus Stephens (Coleoptera: Dytiscidae, Hydroporinae). Aquat. Insects 23: 193-207.

Alarie Y., WatTs C.H.S. \& NiLsson A.N. 2001b: Larval morphology of the tribe Matini (Coleoptera: Dytiscidae: Colymbetinae): descriptions of Batrachomatus daemeli, Matus bicarinatus, and Allomatus nannup and phylogenetic relationships. Can. Entomol. 133: 165-196.

Alarie Y., Michat M.C., Archangelsky M. \& Barber-James H.M. 2007: Larval morphology of Liodessus Guignot, 1939: generic characteristics, descriptions of five species and comparisons with other members of the tribe Bidessini (Coleoptera: Dytiscidae: Hydroporinae). Zootaxa 1516: 1-21.

BERTRAND H. 1968: Larves de coléoptères aquatiques recueillies au Brésil par M.G. Marlier. Bull. Soc. Entomol. Fr. 73: 8-21.

Bertrand H. 1972: Larves et Nymphes des Coléoptères Aquatiques du Globe. F. Paillart, France, 804 pp.

Biströм O. 1982: A revision of the genus Hyphydrus Illiger (Coleoptera, Dytiscidae). Acta Zool. Fenn. 165: 1-121.

Biström O., NilsSON A.N. \& Wewalka G. 1997: A systematic review of the tribes Hyphydrini Sharp and Pachydrini n. trib. (Coleoptera, Dytiscidae). Entomol. Fenn. 8: 57-82.

Crespo F.A. 1996: Descripción del tercer estadio larval de Pachydrus obesus Sharp 1882 (Dytiscidae, Coleoptera). Physis (B) 51(120-121): 1-5.

Goloboff P., Farris J. \& Nixon K. 2003: T.N.T.: Tree analysis using new technology. Program and documentation, available from the authors, and at http://www.zmuc.dk/public/phylogeny.

Kitching I.J., Forey P.L., Humphries C.J. \& Williams D.M. 1998: Cladistics. The theory and Practice of Parsimony Analysis. 2nd ed. Systematics Association publications; 11. Oxford University Press, New York, 228 pp.

LaWrence J.F. 1991: Order Coleoptera. In Stehr F.W. (ed.): Immature Insects. Vol. 2. Kendall/Hunt, Iowa, pp. 144-658.

Мiснат M.C. 2006: The phylogenetic position of Hydrovatus Motschulsky: evidence from larval morphology of $\mathrm{H}$. caraibus Sharp (Coleoptera: Dytiscidae: Hydroporinae). Insect Syst. Evol. 37: 419-432.

Michat M.C. \& Alarie Y. 2006: The larvae of Amarodytes duponti (Aubé) (Coleoptera: Dytiscidae: Hydroporinae), with comments on Bidessini larval morphology and chaetotaxy. Zootaxa 1351: 1-13.
Michat M.C. \& Alarie Y. 2008: Morphology and chaetotaxy of larval Hypodessus cruciatus (Régimbart) (Coleoptera: Dytiscidae: Hydroporinae), and analysis of the phylogenetic relationships of the Bidessini based on larval characters. Stud. Neotr. Faun. Env. 43: 135-146.

Michat M.C. \& Archangelsky M. 2007: Descriptions of larvae of Desmopachria Babington (Coleoptera: Dytiscidae: Hydroporinae): the D. vicina Sharp species group. Coleopt. Bull. 61: 264-276.

Michat M.C. \& TorRes P.L.M. 2005: Larval morphology of Macrovatellus haagi (Wehncke) and phylogeny of Hydroporinae (Coleoptera: Dytiscidae). Insect Syst. Evol. 36: 199-217.

Michat M.C. \& Torres P.L.M. 2006a: Hydaticus tuyuensis Trémouilles (Coleoptera: Dytiscidae): larval morphology and phylogenetic relationships within Dytiscinae. Hydrobiologia 563: 479-492.

Michat M.C. \& Torres P.L.M. 2006b: The unknown larva of Anodocheilus Babington (Coleoptera: Dytiscidae: Hydroporinae: Bidessini): description of A. maculatus Babington and chaetotaxic considerations. Trans. Am. Entomol. Soc. 132: 431-444.

Michat M.C., Archangelsky M. \& Torres P.L.M. 2005: Descriptions of the preimaginal stages of Lancetes marginatus (Steinheil) and L. biremis Ríha (Coleoptera: Dytiscidae), and comparative notes with other Lancetes larvae. Stud. Neotr. Faun. Env. 40: 129-142.

Michat M.C., Alarie Y., Torres P.L.M. \& Megna Y.S. 2007: Larval morphology of the diving beetle Celina and the phylogeny of ancestral hydroporines (Coleoptera: Dytiscidae: Hydroporinae). Invert. Syst. 21: 239-254.

Miller K.B. 2001: On the phylogeny of the Dytiscidae (Insecta: Coleoptera) with emphasis on the morphology of the female reproductive system. Insect Syst. Evol. 32: 45-92.

Miller K.B., Wolfe G.W. \& BiströM O. 2006: The phylogeny of the Hydroporinae and classification of the genus Peschetius Guignot, 1942 (Coleoptera: Dytiscidae). Insect Syst. Evol. 37: 257-279.

NiLsson A.N. 2001: World Catalogue of Insects. Vol. 3. Dytiscidae (Coleoptera). Apollo Books, Stenstrup, 395 pp.

SHARP D. 1882: On aquatic carnivorous Coleoptera or Dytiscidae. Sci. Trans. R. Dublin Soc. 2: 179-1003.

Shaverdo H.V. \& Alarie Y. 2006: Description of the larva of Canthyporus kenyensis Bilardo \& Sanfilippo (Coleoptera: Dytiscidae: Hydroporinae) with implication for the phylogeny of the Hydroporini. Aquat. Insects 28: 113-130.

Spangler P.J. \& Folkerts G.W. 1973: The larva of Pachydrus princeps (Coleoptera: Dytiscidae). Proc. Biol. Soc. Wash. 87: 351-356.

TrÉMOUILLES E.R. 1995: Dytiscidae: Methlinae - Hydroporinae. In Castellanos Z.A. (ed.): Fauna de Agua Dulce de la República Argentina 37(1). Profadu, La Plata, pp. 1-82.

WILey E.O. 1981: Phylogenetics. The Theory and Practice of Phylogenetic Systematics. John Wiley \& Sons, New York, $439 \mathrm{pp}$.

Wolfe G.W. 1985: A phylogenetic analysis of plesiotypic Hydroporinae lineages with an emphasis on Laccornis des Gozis (Coleoptera: Dytiscidae). Proc. Acad. Nat. Sci. Phil. 137: 132-155.

Young F.N. 1980: Predaceous water beetles of the genus Desmopachria Babington: the subgenera with descriptions of new taxa (Coleoptera: Dytiscidae). Rev. Biol. Trop. 28: 305-321. 
ZimmermanN A. 1919: Die Schwimmkäfer des Deutschen Entomologischen Museums zu Berlin-Dahlem. Arch. Naturgesch. 83[1917]: 69-249.

Received January 6, 2008; revised and accepted June 4, 2008

APPENDIX 1. Characters and states used for the parsimony analysis of 34 terminal taxa of Dytiscidae.

(000) Parietal (at level of occipital suture) (instar I): (0) not constricted; (1) constricted.

(001) Parietal (at level of occipital suture) (instars II-III): (0) not constricted; (1) constricted.

(002) Occipital suture (instar I): (0) absent; (1) present

(003) Occipital suture (instars II-III): (0) absent; (1) present.

(004) Stemmata (instars I-II): (0) absent; (1) present.

(005) Egg bursters (instar I): (0) located submedially; (1) located basally

(006) Nasale (instars I-III): (0) broad, subtriangular; (1) narrow, more or less parallel sided; (2) absent

(007) Apex of nasale (instars I-III): (0) not spatulate; (1) spatulate.

(008) Lateral projections of nasale (instars I-III): (0) absent; (1) very small, inconspicuous; (2) well developed, short, not bifid apically; (3) strongly developed, bifid apically.

(009) Row of elongate spinulae on basoventrolateral surface of nasale (instars I-III): (0) absent; (1) present.

(010) Seta FR2 (instar I): (0) inserted close to frontal line; (1) inserted far from frontal line.

(011) Seta FR6 (instar I): (0) not distinctly developed; (1) strongly developed.

(012) Seta FR7 (instar I): (0) spiniform; (1) setiform

(013) Seta FR13 (instar I): (0) present; (1) absent.

(014) Pore FRb (instar I): (0) present; (1) absent.

(015) Seta PA3 (instar I): (0) inserted contiguously to setae PA1 and

PA2; (1) inserted far from setae PA1 and PA2.

(016) Seta PA7 (instar I): (0) present; (1) absent.

(017) Seta PA18 (instar I): (0) present; (1) absent.

(018) Pore PAb (instar I): (0) inserted contiguously to seta PA3; (1) inserted far from seta PA3, close to coronal line or to frontal line.

(019) Pore PAc (instar I): (0) inserted medially (not passing the level of stemmata); (1) inserted distally (anterior to the stemmata); (2) absent.

(020) Pore PAd (instar I): (0) present; (1) absent.

(021) Pore PAe (instar I): (0) present; (1) absent.

(022) Pore PAj (instar I): (0) present; (1) absent.

(023) Pore PAk (instar I): (0) present; (1) absent.

(024) Pore PAl (instar I): (0) present; (1) absent.

(025) Pore PAm (instar I): (0) present; (1) absent.

(026) Pore PAo (instar I): (0) present; (1) absent.

(027) Pore PAp (instar I): (0) present; (1) absent.

(028) Secondary spiniform setae on lateral margin of parietal (instars II-III): (0) absent; (1) present.

(029) Secondary spiniform setae on ventral surface of parietal (instars II-III): (0) present; (1) absent.

(030) Ventroapical spinula on antennomere 3 (instars I-III): (0) absent; (1) present

(031) Seta AN1 (instar I): (0) inserted medially or distally; (1) inserted proximally.

(032) Seta AN3 (instar I): (0) inserted distally; (1) inserted submedially.

(033) Pore ANf (instar I): (0) present; (1) absent.

(034) Pore ANh (instar I): (0) present; (1) absent.

(035) Additional ventroapical pores on antennomere 3 (instar I): (0) present; (1) absent.

(036) Secondary setae on antennomere 1 (instars II-III): (0) absent; (1) present.

(037) Secondary setae on antennomere 2 (instars II-III): (0) absent; (1) present.

(038) Mandible (instars I-III): (0) not oriented obliquely; (1) oriented obliquely.

(039) Sensillum MN2 (instar I): (0) setiform; (1) pore-like.

(040) Pore $\mathrm{MNa}$ (instar I): (0) inserted at about the same level as pore $\mathrm{MNb}$; (1) inserted distal to pore $\mathrm{MNb}$.

(041) Cardo (instars I-III): (0) not fused to the stipes; (1) fused to the stipes.

(042) Galea (instars I-III): (0) well developed, subconical; (1) very short, subconical; (2) minute; (3) absent.
(043) Palpifer (instars I-III): (0) inconspicuous, not clearly differentiated from the stipes; (1) palpomere-like, clearly differentiated from the stipes.

(044) Seta MX1 (instars I-III): (0) inserted on the cardo; (1) inserted on the stipes.

(045) Seta MX4 (instar I): (0) present; (1) absent.

(046) Seta MX5 (instar I): (0) present; (1) absent.

(047) Seta MX6 (instar I): (0) present; (1) absent.

(048) Seta MX7 (instar I): (0) present; (1) absent.

(049) Seta MX8 (instar I): (0) present; (1) absent.

(050) Seta MX9 (instar I): (0) present; (1) absent.

(051) Seta MX10 (instar I): (0) present; (1) absent

(052) Pore MXh (instar I): (0) inserted on the galea; (1) inserted on the stipes; (2) absent.

(053) Pore MXk (instar I): (0) present; (1) absent.

(054) Secondary setae on maxillary palpomere 1 (instars II-III): (0) absent; (1) present.

(055) Prementum (instars I-III): (0) broader than long or as long as broad; (1) longer than broad.

(056) Elongate lateral spinulae on prementum (instars I-III): (0) absent; (1) present.

(057) Labial palpus (instars I-III): (0) composed of one palpomere; (1) composed of two palpomeres.

(058) Ratio MP/LP (instar III): (0) less than 1.90; (1) more than 2.30

(059) Labial palpomere 2 (instars I-III): (0) normal shape; (1) broad, robust, rounded apically (2) inapplicable.

(060) Seta LA1 (instar I): (0) present; (1) absent.

(061) Seta LA2 (instar I): (0) present; (1) absent.

(062) Seta LA3 (instar I): (0) inserted distally or subdistally; (1) inserted proximally; (2) absent.

(063) Seta LA5 (instar I): (0) setiform; (1) spiniform.

(064) Setae LA4 and LA5 (instar I): (0) inserted distally or subdistally;

(1) inserted proximally; (2) absent.

(065) Setae LA4 and LA8 (instar I): (0) short, spiniform; (1) elongate, setiform; (2) elongate, spiniform.

(066) Seta LA6 (instar I): (0) inserted distally or subdistally; (1) inserted medially; (2) absent.

(067) Seta LA8 (instar I): (0) inserted distally or subdistally; (1) inserted proximally; (2) absent.

(068) Seta LA9 (instar I): (0) present; (1) absent.

(069) Seta LA10 (instar I): (0) inserted submedially; (1) inserted distally; (2) absent.

(070) Seta LA12 (instar I): (0) inserted submedially; (1) inserted distally; (2) absent.

(071) Pore LAb (instar I): (0) present; (1) absent.

(072) Pore LAd (instar I): (0) present; (1) absent.

(073) Additional setae on dorsal surface of prementum (instar I): (0) absent; (1) present.

(074) Secondary setae on prementum (instars II-III): (0) absent; (1) present.

(075) Pore COa (instar I): (0) present; (1) absent.

(076) Seta TR2 (instar I): (0) present; (1) absent.

(077) Seta FE2 (instar I): (0) inserted distally; (1) inserted subdistally

(078) Seta FE6 (instar I): (0) inserted distally; (1) inserted subdistally;

(2) absent.

(079) Pore FEa (instar I): (0) present; (1) absent.

(080) Natatory dorsal setae on femur (instars II-III): (0) absent; (1) present.

(081) Natatory ventral setae on femur (instars II-III): (0) absent; (1) present.

(082) Secondary anterodorsal setae on femur (instars II-III): (0) absent;

(1) present.

(083) Seta TI2 on meso- and metatibia (instar I): (0) short, spiniform; (1) elongate, setiform; (2) inapplicable.

(084) Seta TI7 (instar I): (0) short, spiniform; (1) elongate, setiform.

(085) Pore TIa (instar I): (0) present; (1) absent.

(086) Secondary setae on tibia (instars II-III): (0) absent; (1) present.

(087) Natatory dorsal setae on tibia (instars II-III): (0) absent; (1) present.

(088) Secondary setae on anterodorsal margin of protarsus (instars II-III): (0) absent; (1) present.

(089) Secondary setae on posteroventral margin of protarsus (instar III): (0) absent; (1) present. 
(090) Secondary setae on posteroventral margin of metatarsus (instar III): (0) absent; (1) present.

(091) Natatory dorsal setae on tarsus (instars II-III): (0) absent; (1) present.

(092) Basoventral spinulae on claw (instar I): (0) absent; (1) present.

(093) Abdominal tergites I-VI (instar I): (0) with anterior transverse carina; (1) without anterior transverse carina.

(094) Ventral surface of abdominal segments II-III (instar III): (0) membranous; (1) sclerotised.

(095) Ventral surface of abdominal segments IV-V (instar III): (0) membranous; (1) sclerotised.

(096) Ventral surface of abdominal segment VI (instars I-III): (0) membranous; (1) sclerotised.

(097) Abdominal segment VII (instar I): (0) sclerotised dorsally, membranous ventrally; (1) sclerotised dorsally and ventrally, with ventra sclerite separate from dorsal sclerite; (2) completely sclerotised except for a narrow, longitudinal, ventral band; (3) completely sclerotised.

(098) Abdominal sclerite VII (instar I): (0) with anterior transverse carina; (1) without anterior transverse carina.

(099) Spiracles on mesothorax and abdominal segments I-VII (instar III): (0) present; (1) absent.

(100) Siphon (instars I-III): (0) very short; (1) short to moderately long; (2) very long, urogomphomere-like.

(101) Tracheal trunks (instars I-III): (0) not protruding from the apex of siphon; (1) protruding from the apex of siphon.

(102) Sensillum AB2 (instar I): (0) setiform; (1) pore-like; (2) absent.

(103) Seta AB3 (instar I): (0) setiform; (1) spiniform.

(104) Seta AB4 (instar I): (0) not distinctly developed; (1) very elongate, strongly developed.
(105) Seta AB5 (instar I): (0) not distinctly developed; (1) strongly developed.

(106) Seta AB6 (instar I): (0) short (1) elongate.

(107) Seta AB7 (instar I): (0) small; (1) well developed to strongly developed; (2) absent.

(108) Seta AB9 (instar I): (0) inserted dorsolaterally; (1) inserted ventrolaterally.

(109) Seta AB10 (instar I): (0) setiform; (1) spiniform.

(110) Seta AB15 (instar I): (0) absent; (1) present.

(111) Pore ABa (instar I): (0) present; (1) absent.

(112) Pore ABc (instar I): (0) present; (1) absent.

(113) Secondary ventral setae on siphon (instar III): (0) absent; (1) present.

(114) Ratio U/HW (instar III): (0) less than 3.00; (1) more than 3.60.

(115) Setae UR2, UR3 and UR4 (instar I): (0) inserted contiguously; (1) not inserted contiguously; (2) only UR2 and UR3 inserted contiguously; (3) only UR3 and UR4 inserted contiguously.

(116) Seta UR5 (instar I): (0) elongate, setiform; (1) short, spiniform.

(117) Seta UR6 (instar I): (0) elongate; (1) short.

(118) Seta UR8 (instar I): (0) inserted terminally on urogomphomere 2; (1) inserted subapically on urogomphomere 2; (2) inserted submedially on urogomphomere $2 ;(3)$ inserted proximally on urogomphomere 2; (4) absent; (5) inserted on urogomphomere 1.

(119) Pore URb (instar I): (0) proximal to seta UR2; (1) contiguous to seta UR2; (2) distal to seta UR2; (3) absent.

(120) Additional pores on urogomphus (instar I): (0) absent; (1) present.

(121) Secondary setae on urogomphus (instars II-III): (0) absent; (1) present.

APPENDIX 2. Data matrix of 122 larval characters for 34 terminal taxa of Dytiscidae. "?" - missing data.

\begin{tabular}{|c|c|c|c|c|c|c|c|c|c|c|c|c|}
\hline \multirow[t]{4}{*}{ Species } & \multicolumn{12}{|c|}{ Character } \\
\hline & 0 & 0 & 0 & 0000 & 00000 & 00000 & 00000000 & 0 & 0 & 0 & 111 & 1 \\
\hline & 001 & 1111111112 & 22222223 & 3333333334 & 4444444445 & 5555555556 & 6666666667 & 7777777778 & 8888888889 & 9999999990 & 0000000001 & 11111111122 \\
\hline & 01234567890 & 1234567890 & 1234567890 & 1234567890 & 1234567890 & 1234567890 & 1234567890 & 1234567890 & 1234567890 & 1234567890 & 1234567890 & 12345678901 \\
\hline Agabus anthracinus & 01001020000 & $01 ? 0000000$ & $00000001 ? 1$ & 0000100000 & 0010000000 & 0010001000 & 0010000011 & 0000000000 & $0 ? 00010 ? ? ?$ & $00 ? 000 ? ? 0 ?$ & 00000 & $000 ?$ \\
\hline Hydaticus tuyuensis & 1111020000 & $01 ? 0000000$ & 0000000101 & 0100110001 & 0010000000 & 0010001000 & 0010000011 & 0001000201 & 1101011100 & 1100002000 & 0000000001 & 0000 \\
\hline Laccophilus maculosus & 00001120000 & $01 ? 0000020$ & 0000000100 & 0100100000 & 0010000000 & 0010001100 & 0210000022 & 0000000000 & 0000011100 & 1010000101 & 0000000101 & 00001005001 \\
\hline Lancetes marginatus & 11001020000 & $01 ? 0000000$ & 0000000101 & 1100000000 & 0010000000 & 0010001000 & 0010000001 & 0010000000 & 0001011000 & 1010000100 & 0000000001 & 000110050 \\
\hline Matus bicarinatus & 00111020000 & $01 ? 0000000$ & $00000001 ? 1$ & 1000011000 & 0010000000 & 0011001000 & 0010200011 & 0001000001 & 0120011 & 1000001001 & 0000000001 & 00002005201 \\
\hline Rhantus signatus & 11111020000 & $01 ? 0000000$ & 0000000101 & 1000000000 & 0010000000 & 0010001000 & 0010000011 & 0011000001 & 0101011101 & 1100000000 & 0000000001 & 00001005001 \\
\hline Amarodytes duponti & 00111000100 & 0000111101 & 1111001111 & 0110100110 & 1301100011 & 1110001000 & 0000100000 & 0000010010 & 0100010000 & 0010001101 & 0000 & 1100 \\
\hline Anodocheilus maculatus & 00011000100 & 0000111101 & 1101001010 & 0110100110 & 1301100011 & 1100001000 & 0000100000 & 0000010010 & 0100010000 & 0010001101 & $000000 ? 110$ & 110010010 \\
\hline Hypodessus cruciatus & 00011000100 & 0000111101 & 1101001111 & 0110100110 & 1301100011 & $11 ? 0001000$ & 0000100000 & 0000010010 & 0100010011 & 0010001101 & 0000000110 & 11001 \\
\hline Liodessus flavofasciatus & 00011000100 & 0000111101 & 1101001010 & 0110100110 & 1301100011 & 1100001000 & 0000100000 & 0000010010 & 0100 & 001 & 00 & 1 \\
\hline Antiporus uncifer & 00011011200 & 0000111101 & $00010011 ? 0$ & 0110100111 & 1301100011 & 11000 & 0000100000 & 0000010001 & 0100011111 & 1000001000 & 0000 & 1001 \\
\hline Canthypo & 011000100 & 0000011101 & $10010010 ? 0$ & 0100100111 & 0300000011 & 1100011000 & 1000100000 & 0000000010 & 0000000000 & $00 ? 000 ? ? 01$ & 0001 & 100 \\
\hline Deronectes latus & 00011000101 & 000 & $10010011 ? 1$ & $? 100$ & 03001 & $0001 ? 00$ & 000 & 000 & 01 & 0 & 0000 & $100:$ \\
\hline Heterosternuta wickhami & 00011000100 & 0000111101 & $10010011 ? 1$ & $010010011 ?$ & 0300100011 & 1100011000 & 0000100000 & 0000010000 & 0100010010 & 0010001110 & 00000 & 10002 \\
\hline Hydrocolus paugus & 0100 & 0000111101 & $10010011 ? 1$ & $010010111 ?$ & 0300100011 & 1100 & 0000100000 & 0000000000 & 0100010000 & 00100 & 000 & 100 \\
\hline Hydroporus columbianus & 00011000100 & 0000111101 & $10010011 ? 1$ & $010010011 ?$ & 0300100011 & 1100011000 & 0000100000 & 0000000000 & 0100010000 & 0010001101 & 0000000100 & 1000200110 \\
\hline Laccornellus lugubris & $0 ? 0 ? 1000101$ & 0000011101 & $0001001 ? ? 0$ & $01001 ? ? 111$ & 0100000000 & $100 ? 011 ? 00$ & 1000100000 & $000 ? 00001 ?$ & ??000????? & $? 00 ? ? 010 ? 1$ & 0001010011 & $00 ? ? 000410 ?$ \\
\hline Neoporus undulatus & 200 & 1 & 1 & 1 ? & 11 & 100 & 00 & 00 & 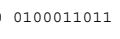 & 1 & 0 & \\
\hline Oreodytes scitulus & 11111000100 & 0000111101 & $10010011 ? 1$ & 0010100111 & 1301100011 & 1100001000 & 0000100000 & 0000000000 & 0100010000 & 0000001000 & 0000000100 & $10001001 ?$ \\
\hline Scarodytes halensis & 11111000100 & 0000111101 & $10010011 ? 1$ & ?01010011? & 1301100011 & $1100011 ? 00$ & 0000100000 & 0000000001 & 0100011011 & 1000001001 & $0000000 ? 00$ & $10002001 ? 0$ \\
\hline Stictonectes canariensis & 100 & 01 & $? 1$ & $1 ?$ & 011 & 100 & 00 & 00 & 0 & o & 0 & 1 \\
\hline Hydrovatus caraibus & 00001110001 & 0100011101 & 1101111010 & 0101100101 & 1101000000 & 1000001000 & 1200101000 & 0000010010 & 0000000000 & 0101111001 & 0001110010 & 10100004100 \\
\hline Coelambus impressopunctatus & 500011000100 & 0000111101 & $00010011 ? 0$ & $011010011 ?$ & 0300000011 & $1100011 ? 00$ & 0000100000 & 0000010100 & 0100010011 & 0010001101 & 0000000100 & 10002002100 \\
\hline Herophydrus musicus & 00011000100 & 000 & 00 & $11 ?$ & 011 & 00 & 0 & 0000 & o & o & 00 & 1 \\
\hline Hygrotus sayi & 00011000100 & 0000111101 & $00010011 ? 0$ & $011010011 ?$ & 0300000011 & $1100011 ? 00$ & 0000100000 & 0000010100 & 0100010011 & 0010001101 & 0000000100 & 10002002100 \\
\hline Andex insignis & 00011010100 & 0001111111 & 1101001101 & 0111100111 & 1301000011 & $11 ? 0101000$ & 0000101001 & 0001010011 & 0101111111 & $100011 ? 001$ & 0100111110 & 10003103101 \\
\hline Desmopachria concolor & 00011010000 & 010111111 & 1101001001 & 0111100111 & 1301111011 & 1100101010 & 0101111011 & 1010010011 & 0101011111 & 1011111101 & 0100111110 & 101001033 \\
\hline Desmopachria punctatiss & 00011010000 & 0101111111 & 1101001001 & 0111100111 & 1301111011 & 1100101010 & 0101111011 & 1010010011 & 0101011111 & 1011111101 & 0100111110 & 10100103301 \\
\hline Hyphydrus ovatus & 00011011000 & 010111111 & 1101001101 & ??1110011? & 1301000011 & 1100101000 & 0000101001 & 0000010011 & 0101011111 & 1000111001 & 0100111110 & 10103103001 \\
\hline Microdytes uепо i & 00011000100 & 0101011111 & 1101001101 & ??1110011? & 1301000011 & 1100101000 & 0000101001 & 0000010010 & 0100011111 & 1001111001 & 0100111110 & 10000003101 \\
\hline Pachydrus obesus & 00001011210 & 0000011101 & 0001001110 & 0101000111 & 1201111100 & 1200001001 & 0000101011 & 1001111110 & 1011010000 & 0000012001 & 0110000110 & 10102002101 \\
\hline Laccornis latens & 00011000000 & 0010011100 & 0001001100 & $000010011 ?$ & 0100000000 & $1010001 ? 00$ & 0000100000 & 0000000010 & 0000000000 & 0000001001 & 0000000100 & 00000000100 \\
\hline Celina parallela & 01111000001 & 0000110100 & 0001001110 & 1100100101 & 0100000000 & 0000001000 & 0200100011 & 0000000000 & 0100010111 & 0000001001 & 1000012100 & 10100010100 \\
\hline Vatellus haagi & 00011011300 & 1100110101 & 0001101111 & 0110011111 & 1301100111 & $11 ? 1010120$ & 1010100122 & 0100010000 & 0101011111 & 1010001102 & 0200011110 & 10011000101 \\
\hline
\end{tabular}

